\title{
The East Greenland Boundary Current System South of Denmark Strait
}

\author{
J. Alexander Brearley ${ }^{1 *}$ \\ Robert S. Pickart ${ }^{2}$ \\ Hedinn Valdimarsson ${ }^{3}$ \\ Steingrimur Jonsson ${ }^{4}$ \\ Raymond W. Schmitt ${ }^{2}$ \\ Thomas W.N. Haine ${ }^{5}$
}

${ }^{1}$ Ocean and Earth Science, National Oceanography Centre Southampton, University of Southampton Waterfront Campus, European Way, Southampton, SO14 3ZH, UK.

${ }^{2}$ Woods Hole Oceanographic Institution, Woods Hole MA 02543, USA.

${ }^{3}$ Marine Research Institute, Reykjavik, Iceland.

${ }^{4}$ University of Akureyri, Akureyri, Iceland.

${ }^{5}$ Morton K. Blaustein Department of Earth and Planetary Sciences, Johns Hopkins

University, Olin Hall, $34^{\text {th }}$ and North Charles St., Baltimore MD 21218, USA.

* Corresponding author jab5@noc.soton.ac.uk. January 1, 2012

\begin{abstract}
Four repeat sections across the East Greenland shelf and slope south of Denmark Strait are analysed to investigate the components of the boundary current system. The sections were occupied in summer 2001, 2003, 2004, and 2007, and included use of a vessel-mounted acoustic Doppler current profiler, enabling the computation of absolute geostrophic velocities. The components of the boundary current are the East Greenland/Irminger Current (EGIC) in the upper layer, the Deep Western Boundary Current (DWBC) at the base of the continental slope, and the East Greenland spill jet which resides inshore and beneath the EGIC. Special emphasis is placed on the spill jet, a recently discovered feature about which relatively little is known. The spill jet was observed in each occupation, transporting 5.0 $\pm 2.2 \mathrm{~Sv}$ equatorward in the mean, which is similar to the DWBC at this latitude $(4.9 \pm 1.4 \mathrm{~Sv})$. The spill jet displayed considerable variability between sections, which appears to be linked to the geographical location of the upper-layer hydrographic front associated with the EGIC. When the front is located near the shelfbreak, the spill jet is confined to the outer shelf/upper slope and its transport is smaller. During these times there is less mixing and the water advected by the jet is generally lighter than that transported by the DWBC. In contrast, when the front is located seaward of the shelfbreak, the spill jet extends farther down the continental slope and its volume flux is larger. At these times, there is stronger mixing and the spill jet can transport water as dense as the Denmark Strait Overflow Water. A vorticity analysis indicates that the jet is susceptible to a variety of instability processes including baroclinic, barotropic, and symmetric instability. In addition, it is subject to double diffusive mixing that may influence its downstream evolution. It appears that the
\end{abstract}


spill jet is a permanent feature of the summertime circulation in this region and contributes significantly to the intermediate, and at times deep, limb of the Atlantic Meridional Overturning Circulation.

\section{Keywords}

East Greenland Boundary Current, Denmark Strait Overflow Water, interannual variability, overturning, mixing.

\section{Introduction}

Along the East Greenland continental shelfbreak to the south of Denmark Strait there exists a sharp hydrographic front separating cold and fresh Arctic-origin water onshore from warm and salty Atlanticorigin water farther offshore. The jet associated with this hydrographic front both recirculates Atlantic water within the Irminger Sea and provides a pathway by which Arctic water can exit southwards into the North Atlantic. The combined flow of these two components is often referred to as the East Greenland/Irminger Current (EGIC) (Figure 1). Early observations in the region suggested that the front and its jet were both variable in time and unstable, with intrusions of warm Irminger Water regularly found on the inshore side of the front (Defant, 1930). Subsequent studies, such as the IGY program of 1957-8 (Dietrich, 1964) and the NORWESTLANT program (Lee, 1968), confirmed the variability of the boundary current system, with wind-driven changes in the inflow of Atlantic Water into the Irminger Basin being postulated as a control on the transport and composition of the EGIC (Blindheim, 1968). Other observational efforts have documented the presence of an inshore branch of the boundary current system, now known as the East Greenland Coastal Current (Malmberg et al., 1967; Bacon et al., 2002; Sutherland et al., 2008), though this feature is not considered further in the present study.

In spite of numerous observational programs through the years, the transport estimates for the EGIC remain poorly constrained. For instance, while Bacon et al. (1997) calculated a value of 15.0 Sv based on an ocean inverse from the CONVEX-91 experiment close to Cape Farewell, Pollard et al. (2004) 
reported a much smaller transport value of 7.0 Sv (referenced to $1400 \mathrm{~m}$ ). Furthermore, the kinematics and dynamics of the EGIC are not well understood. This is because of a lack of synoptic hydrographic data close to the shelfbreak, meaning that the front and its jet have not been fully resolved. A highresolution hydrographic/velocity section conducted in 2001 (Pickart et al., 2005) noted for the first time a hitherto unknown component of the boundary current system termed the "spill jet", identifiable in that section as a bottom-intensified southward flow over the depth range $250-800 \mathrm{~m}$. This feature, postulated by Rudels et al. (1999, 2002), was located beneath and inshore of the EGIC. It was also distinct from the deeper equatorward flow of Denmark Strait Overflow Water (DSOW) within the Deep Western Boundary Current (DWBC) at the base of the continental slope. The synoptic transport of the spill jet was 1.9 Sv southwards towards Cape Farewell. Pickart et al. (2005) argued that this feature was caused by the cascading of dense shelf water over the continental shelfbreak, entraining ambient Atlantic water in the process. The spill jet could therefore form a significant contribution to the intermediate component of the North Atlantic meridional overturning circulation, at the density level of the Labrador Sea Water.

Recently, high-resolution modelling of the spill jet for the period of summer 2003 has suggested that it is a permanent feature in the region south of Denmark Strait with a mean transport of $4.9 \pm 1.7 \mathrm{~Sv}$ southwards (Magaldi et al., in press). Moreover, substantial variability in both the transport of the jet and its position relative to the continental slope was observed in the model. During some periods, the model spill jet was located close to the shelfbreak, while at other times the jet was positioned part way down the continental slope with a velocity core as deep as $1000 \mathrm{~m}$. Magaldi et al. (in press) identified two mechanisms controlling the strength of the jet. In the first, a transport maximum in the spill jet was found to be associated with isolated lenses of dense water cascading off the shelf. No simple correlation was observed between these spilling events and the local wind stress (Haine et al., 2009). In the second mechanism, the maximum in spill jet transport was associated with the passage of surface frontal 
meanders that were in turn linked to deep pulses of DSOW of the type studied by Spall and Price (1998). In particular, as an eddy of DSOW passed through the region, the leading/seaward edge of the feature drew dense water from the outer shelf which quickly descended to depth, feeding the spill jet.

While progress has been made regarding the structure and behaviour of the spill jet, numerous important issues remain to be addressed concerning the nature of the jet and its relation to the other components of the East Greenland boundary current system. Firstly, the spatial and temporal variability of the boundary current system from year-to-year needs to be quantified, with particular focus on whether the spill jet is a permanent feature of the region south of Denmark Strait. The transport of the individual components of the boundary current system (the EGIC, spill jet, and DWBC) should be established over a number of realizations to quantify both the mean transport and variability in each part of the system. An analysis of the $\mathrm{T} / \mathrm{S}$ properties of the spill jet is also required, in order to help resolve the origin of the spill jet water and to explain its downstream evolution as it approaches Cape Farewell. Evidence for two-way cross frontal exchange within the boundary current has already been noted (e.g. Pickart et al., 2005), but further examination of the potential vorticity fields is required to shed light on the main mechanisms causing the exchange of mass and properties between the shelf and the interior of the Irminger Basin. Finally, given the close proximity of warm, salty Irminger Water and cold, fresh Arctic-origin water near the hydrographic front, there exists the potential for double diffusive mixing which may in turn impact the hydrographic structure of the spill jet. The present study addresses the above-mentioned issues using a collection of shipboard measurements of the spill jet made between 2001 and 2007.

\section{Data and Methods}

Hydrographic and velocity data were collected during four summer shipboard surveys from a section $200 \mathrm{~km}$ to the southwest of Denmark Strait (Figure 2). These cruises were conducted in August 2001, 
August 2003, August 2004 and September 2007 aboard R/V Oceanus (cruises 369 and 385), RRS James Clark Ross (cruise 105), and R/V Arni Fridriksson (cruise A200711). The sections took $11 \mathrm{~h}, 15 \mathrm{~h}, 15 \mathrm{~h}$ and $58 \mathrm{~h}$ respectively to cross the Spill Jet and DWBC. The 2007 section had a longer duration as a mooring array was also deployed along the line, though the results from these instruments are not considered in this paper. The 2001 section was discussed in detail by Pickart et al. (2005) and is included here for completeness.

The number of hydrographic stations across the boundary current varied by year, from 7 in 2007 (covering the outer shelf and slope) to 26 in 2004 (including $70 \mathrm{~km}$ of the continental shelf), but in each year the shelfbreak region itself was densely sampled, sometimes with station spacing as small as $2 \mathrm{~km}$. Temperature, conductivity and pressure were recorded using a Seabird 911+ conductivity/temperature/depth (CTD) system that incorporated both dissolved oxygen measurements and a water-sampling rosette. The CTD salinity was calibrated using the in situ water samples and the temperature was calibrated in the laboratory; resulting accuracies for these variables are 0.002 and $0.001^{\circ} \mathrm{C}$ respectively. Temperature, salinity and potential density data were pressure-averaged into $2 \mathrm{db}$ bins. Following this, vertical sections of various properties were constructed by interpolating onto a uniform grid using a Laplacian-spline routine. The cross-stream origin of the vertical sections $(x=0 \mathrm{~km}$ in the figures) corresponds to the starting point of the single-beam bathymetry data collected on the 2004 section, which is displayed in the subsequent figures. Due to the inhomogeneous station spacing in the sections (close station spacing on the shelf and shelfbreak, coarser spatial resolution offshore), the CTD data were gridded twice. Firstly, the stations offshore of $x=75 \mathrm{~km}$ were gridded at $5 \mathrm{~km}$; these gridded data plus the ungridded station data inshore of $75 \mathrm{~km}$ were then gridded again at $2 \mathrm{~km} \times 5 \mathrm{~m}$ spacing. Minor adjustments were made in the vicinity of the shelfbreak to remove physically implausible density discontinuities caused by interpolating close to a sloping boundary. 
Velocities were obtained using a vessel-mounted acoustic Doppler current profiler (ADCP). $R / V$ Oceanus was equipped with a $150 \mathrm{kHz}$ narrow-band ADCP supplied by RD Instruments, while $R R S$ James Clark Ross and R/V Arni Fridriksson had $75 \mathrm{kHz}$ narrow-band units. Data were collected in $8 \mathrm{~m}$ bins, with the center of the top bin situated at $17 \mathrm{~m}, 13 \mathrm{~m}, 13 \mathrm{~m}$ and $12 \mathrm{~m}$ respectively in 2001, 2003, 2004 and 2007. The barotropic tidal component of velocity was removed using an updated version of the Oregon State University Ocean Topography Experiment/Poseidon Cross-Over Global Inverse Solution (Egbert et al., 1994, 2002). Finally, the ADCP profiles were rotated into stream coordinates following the method of Fratantoni et al. (2001) and gridded onto the same $2 \mathrm{~km} \times 5 \mathrm{~m}$ grid used for the hydrographic variables. More details of the ADCP processing and coordinate rotation are given in Pickart et al. (2005). Absolute geostrophic velocities were computed by referencing the thermal wind shear with the gridded ADCP data following the method in Pickart et al. (2005). The magnitude of the ADCP errors are discussed below in Appendix A. Finally, using the gridded hydrographic and velocity fields, we constructed vertical sections of Richardson Number and Ertel potential vorticity.

Additional hydrographic and velocity data obtained north and south of the repeat line, including the regions of Denmark Strait and Cape Farewell, are used in the study (see Figure 2). The collection, processing, and accuracy of these data were similar to that described above. For more information on these data sets the reader is referred to Pickart et al. (2005) and Våge et al. (2011).

\section{Results}

\subsection{Temperature and Salinity Structure of the Boundary Current System}

In each of the four years a sharp hydrographic front was observed between the cold, fresh East Greenland Current Water and the relatively warm, salty retroflected Irminger Current Water (Figure 3), 
although there was significant variation between the years. In 2001 and 2003 the front was located inshore of the shelfbreak, while in 2004 and 2007 it was offshore of the shelfbreak. In 2003, the Irminger Water penetrated particularly far onshore and conditions on the outer shelf and upper slope were the warmest and saltiest of all the occupations. In three of the four years, an isolated lens of Irminger Water resided on the shelf (two such lenses were present in 2004). This variability in frontal position and the presence of warm, salty lenses on the inshore side of the front is consistent with previous work suggesting strong meandering of the current system perhaps leading to eddy formation in the upper layer (e.g. Defant, 1930). Such cross-stream fluxes appear to operate in both directions since fresh East Greenland Current water can be found seaward of the shelfbreak (e.g. at station 66 in 2004, Figure 3f). It should be noted that the presence of warm and saline water inshore of the front might also be the result of the retroflection of the Irminger Current farther to the north, which is believed to be influenced by winds (Blindheim, 1968).

The mean hydrographic sections of the four occupations (2001-2007) are displayed in Figure 4. The mean front between the Atlantic- and Arctic-origin waters in the upper layer, distinguishable by the rapid transition from cold and fresh to warm and salty conditions, is located over the $1000 \mathrm{~m}$ isobath. Detached Atlantic Water on the shelf is evident in the mean as well, situated above a layer of cold, dense water $\left(>27.7 \mathrm{~kg} \mathrm{~m}^{-3}\right)$ on the outer shelf. Farther offshore, a wedge of cold and fresh DSOW resides on the continental slope at depths greater than $1000 \mathrm{~m}$ (the approximate depth where the $27.8 \mathrm{~kg} \mathrm{~m}^{-3}$ density contour intersects the bottom). The downward-sloping isopycnals in this region indicate the enhanced equatorward geostrophic flow of the DWBC (Figure 5, positive velocities are equatorward). One of the most prominent aspects of the mean hydrographic sections is the strong thermal wind shear in the region of the upper slope (from the shelfbreak to roughly $x=78 \mathrm{~km}$ in the cross-stream direction). This is indicative of enhanced equatorward flow at depth, a feature also observed by Pickart et al. (2005) in their synoptic crossing in 2001 associated with the spill jet. Interestingly, this sense of shear is 
opposite to what is observed farther south in the upper part of the boundary current system near Cape Farewell (Daniault et al., 2011). This is discussed further in Section 3.7.

\subsection{The spill jet}

The downward-sloping isopycnals near the upper slope, evident in the mean hydrographic sections (Figure 4), were also observed in each of the four individual sections. In 2007, for instance, the $27.7 \mathrm{~kg} \mathrm{~m}^{-3}$ isopycnal descended from $300 \mathrm{~m}$ at the shelfbreak to approximately $900 \mathrm{~m}$ in the Irminger Basin (Figure 3g). Using the 2001 section, Pickart et al. (2005) attributed the isopycnal slope, and the corresponding equatorward flow, to dense water cascading over the shelfbreak creating a shallower and lighter version of the DSOW. The hydrographic fields in the 2001 section supported their interpretation, with relatively cold, fresh and well-ventilated water found close to the bottom at the shelf edge and along the upper continental slope (Pickart et al., 2005). From their analysis, the total transport of the East Greenland spill jet in that year was 1.9 Sv.

The calculated absolute geostrophic velocities from 2003, 2004 and 2007 confirm the presence of the spill jet in all four sections, suggesting it is a permanent feature of the region, at least during the summer months. The mean alongstream geostrophic velocity section of the four years is shown in Figure 5 (positive is equatorward). Strong bottom-intensified equatorward flow is found between $200 \mathrm{~m}$ and the bottom, banked against the upper continental slope and along the outer shelf edge - this is the spill jet. In the mean, the jet is centered at roughly the $800 \mathrm{~m}$ isobath and its offshore edge abuts the DSOW near the $1100 \mathrm{~m}$ isobath (the enhanced flow of the DWBC is evident farther downslope). Consistent with the results of Pickart et al. (2005), a component of the mean spill jet resides on the outer continental shelf. This is believed to be southward-flowing dense water that has yet to cascade (discussed further below). The magnitudes of the mean velocities in the spill jet are impressively large (greater than $1 \mathrm{~m} \mathrm{~s}^{-1}$ in the 
core of the flow, and more than $0.6 \mathrm{~m} \mathrm{~s}^{-1}$ for the component on the outer shelf). Inspection of the mean fields also shows enhanced equatorward flow in the upper layer near the location of the hydrographic front (roughly $x=78 \mathrm{~km}$ ). This is the signature of the surface-intensified EGIC. It is more evident in some of the individual sections.

The spill jet, as well as the other components of the boundary current system, displays substantial variability between the occupations (Figure 6). In particular, the lateral position, vertical extent, and strength of the spill jet vary. In the first two occupations, 2001 and 2003 (Figure 6a,b), the core of the jet was confined to the upper slope/outer shelf (inshore of the $800 \mathrm{~m}$ isobath) and its magnitude was weaker. Magaldi et al. (in press) conducted a model study of the spill jet during summer 2003, which encompassed the period of the 2003 observations. While it should not be expected that the model results be in perfect phase with the observations, their high-resolution simulation does indicate a period of limited spilling similar to the hydrographic section, which is then followed by a considerable amount of dense water cascading off the shelf. This transition occurs over a timescale of two days, strengthening the spill jet and causing it to deepen and partly merge with the upper part of the DSOW. According to Magaldi et al. (in press), there is at times little or no distinction between the densest part of the spill jet and the lightest part of the deep overflow. This in turn implies that water with the properties of DSOW (denser than $\sigma_{\theta}=27.8 \mathrm{~kg} \mathrm{~m}^{-3}$ ) can occasionally remain on the continental shelf south of Denmark Strait and subsequently cascade off the shelf downstream of the sill. Note in the 2003 occupation that the shoreward part of the overflow water (between 80 and $90 \mathrm{~km}$ ) extends quite high in the water column (Figure $6 \mathrm{~b}$ ). It is possible that this is spill jet water that previously drained off the shelf upstream of the section (but downstream of Denmark Strait), partially joining the DWBC. Such a scenario is discussed later in the paper. However, given both the density range of this feature (as dense as $\sigma_{\ominus}=27.9 \mathrm{~kg} \mathrm{~m}^{-3}$ ) and its elevated oxygen concentration (not shown), we consider this portion of the boundary current in the 2003 section as part of the DSOW (not the spill jet) when calculating transports in Section 3.3. 
In the latter two occupations, 2004 and 2007 (Figure 6c,d), the spill jet is significantly stronger and extends farther down the continental slope (core depth near the $1000 \mathrm{~m}$ isobath). In 2004, the jet's peak equatorward velocity exceeds $1.6 \mathrm{~m} \mathrm{~s}^{-1}$ due to the extremely strong isopycnal tilt offshore of $x=65 \mathrm{~km}$. Such high spill jet velocities and the associated intense lateral shear are shown below to be conducive for instability of the current. Note that these two realizations with a stronger, deeper spill jet are the two instances when the EGIC hydrographic front was located offshore of the shelfbreak (Figure 3).

\subsection{Transports}

The three components of the boundary current system considered here are the spill jet, the EGIC, and the DWBC. In all four occupations the DWBC is evident near the base of the continental slope, generally close to the $1400 \mathrm{~m}$ isobath. In the mean it has a velocity maximum of $0.7 \mathrm{~m} \mathrm{~s}^{-1}$ (Figure 5), but synoptically the flow exceeded $1 \mathrm{~m} \mathrm{~s}^{-1}$. The current is generally well ventilated, though the regions of maximum oxygen concentration and peak velocity do not always coincide (e.g. in 2001, see Pickart et al., 2005). Furthermore, because southward velocities occur from the shelfbreak to at least $1500 \mathrm{~m}$ in all years, the minimum in velocity separating the spill jet and the deep overflow is often greater than $0.2 \mathrm{~m} \mathrm{~s}^{-1}$ (Figure 6). Only in 2003 does the velocity minimum fall below $0.05 \mathrm{~m} \mathrm{~s}^{-1}$. Previous studies have typically used $\sigma_{\theta}=27.8 \mathrm{~kg} \mathrm{~m}^{-3}$ as the delimiting isopycnal of DSOW (e.g. Dickson and Brown, 1994), yet there is evidence in both the velocity and oxygen fields that a lighter isopycnal may at times be more appropriate at this location. In 2003, for instance, well-ventilated, southward-flowing dense

water as light as $\sigma_{\theta}=27.7 \mathrm{~kg} \mathrm{~m}^{-3}$ was observed (Figure 6b). Moreover, there is variation in the offshore position of the deep current. For example, in 2007 its offshore extent was $95 \mathrm{~km}$, while in 2001 there was significant southward flow as far offshore as $120 \mathrm{~km}$ (not shown). In order to ensure that transport estimates were consistent between the sections, any flow of the DSOW offshore of $102 \mathrm{~km}$ was 
discounted to prevent year-to-year transport fluctuations from arising due to different spatial sampling. The effect of this limit on the DWBC transport estimate is discussed further below.

The position and strength of the surface-intensified EGIC near the hydrographic front also vary between the individual occupations. Although the mean velocity section (Figure 5) suggests two distinct maxima, this occurs because of spatial variability in the position of the current in the four years and does not represent a separated "East Greenland Current" and "Irminger Current". When calculating the transports of this component of the boundary current system, flow inshore of $x=56 \mathrm{~km}$ along the section was discounted, to allow comparison between the 2001-2004 sections and 2007 section (which did not extend so far inshore).

In order to obtain consistent transport estimates from year to year, a number of approaches were tested. Boundaries based solely on density criteria were found to be inadequate, as the upper bound of the classic DSOW $\left(\sigma_{\theta}=27.8 \mathrm{~kg} \mathrm{~m}^{-3}\right)$ does not always include all of the deep overflow water. Moreover, while the spill jet generally has T/S properties intermediate between those of the EGIC and DSOW (see Section 3.5), the $\mathrm{T} / \mathrm{S}$ characteristics vary between the individual sections, meaning that a single $\mathrm{T} / \mathrm{S}$ or density criterion is not appropriate for all years. To circumvent these problems, a combination of density classes and lateral boundaries were used after examination of the temperature, salinity, velocity and dissolved oxygen sections for each year. The results are presented in Table 1, with more details of the choice of boundaries given in Appendix B (the boundaries are displayed in Figure 6). The uncertainty on the transports is calculated from the ADCP errors, details of which are discussed in Appendix A. For the DWBC we give two estimates, one for $\sigma_{\theta}>27.7 \mathrm{~kg} \mathrm{~m}^{-3}$, and, for comparison with previous studies, a second estimate for $\sigma_{\theta}>27.8 \mathrm{~kg} \mathrm{~m}^{-3}$.

The spill jet is a significant component of the boundary current system in all years, with a mean 
transport of 5.0 Sv (standard error 2.2 Sv). The transport is especially large in 2004 (10.4 Sv) and also elevated in 2007 (4.6 Sv); in both cases the core of the jet is located offshore near the $1000 \mathrm{~m}$ isobath and the current extends over a large depth range. By contrast, in the 2001 and 2003 realizations, when the spill jet is confined to the shelf edge and upper slope, its transport is smaller $(2.7 \mathrm{~Sv}$ and $2.2 \mathrm{~Sv}$, respectively). The EGIC has a mean transport of $6.8 \mathrm{~Sv}$ (standard error $1.2 \mathrm{~Sv}$ ), with the largest transport in $2003(10.7 \mathrm{~Sv})$ and the smallest in 2007 (3.1 Sv). Using the broader definition for DSOW $\left(\sigma_{\theta}>27.7 \mathrm{~kg} \mathrm{~m}^{-3}\right)$, the deep overflow transport is $4.9 \mathrm{~Sv}$ with a standard error of $1.4 \mathrm{~Sv}$, while using Dickson and Brown's (1994) definition of $\sigma_{\theta}>27.8 \mathrm{~kg} \mathrm{~m}^{-3}$, the value is $2.5 \pm 0.8 \mathrm{~Sv}$. This is notably smaller than Dickson and Brown's (1994) mean estimate of $5.2 \mathrm{~Sv}$ at this location.

This difference in DWBC transport denser than $\sigma_{0}=27.8 \mathrm{~kg} \mathrm{~m}^{-3}$ is likely accounted for to some degree by the transport offshore of $102 \mathrm{~km}$ not included in our estimate. Unfortunately, hydrographic data offshore of this limit were only collected in 2001 and 2003. In both cases, a single station was sampled close to $120 \mathrm{~km}$ along the section. Extending the horizontal transport integration in 2003 to $124 \mathrm{~km}$ offshore increases the DWBC transport below $\sigma_{\theta}=27.7 \mathrm{~kg} \mathrm{~m}^{-3}$ by $3 \mathrm{~Sv}$ to $8.8 \mathrm{~Sv}$, with an increase of $1 \mathrm{~Sv}$ below $\sigma_{\theta}=27.8 \mathrm{~kg} \mathrm{~m}^{-3}$ to $3.9 \mathrm{~Sv}$. A similar transport increase of the water below $\sigma_{\theta}=27.8 \mathrm{~kg} \mathrm{~m}^{-3}$ was observed in 2001 (from 2.0 Sv to $3.4 \mathrm{~Sv}$ ). It is thus likely that our DWBC estimates are biased low by this missing contribution. Nevertheless, even assuming the missing contribution is as large as in 2003 in every occupation ( $\mathrm{Sv}$ ), the spill jet remains nearly comparable in magnitude to the DWBC, and, in years such as 2004, is likely larger than the deep overflow.

As noted earlier, the modelling results of Magaldi et al. (in press) suggest that spilling events are often triggered by DSOW eddies that are transiting equatorward along the continental slope and drawing dense water off the shelf. It is unknown to what degree these eddies are being advected by the background current or are self propagating (e.g. Nof, 1983). Unpublished data from farther downstream 
indicate that DSOW eddies are easily detectable in both density and velocity, with the eddy core being located in the middle of the water column. Consequently, it appears that none or our crossings sampled strong eddy features. We note that the 2004 section does show a region of weak poleward flow offshore of the spill jet near $x=85 \mathrm{~km}$ and centred at a depth of $500 \mathrm{~m}$. However, integrating across the feature shows that there is minimal biasing in our equatorward transport values for that section. In the 2007 crossing there is significant poleward flow seaward of the DWBC (offshore of $x=95 \mathrm{~km}$ ). The velocity structure here is not indicative of an eddy, but if it were then our 2007 transport estimate for DSOW denser than $\sigma_{\theta}>27.7 \mathrm{~kg} \mathrm{~m}^{-3}$ would be reduced from 1.6 Sv to $1.1 \mathrm{~Sv}$ (obtained by subtracting an equal amount of equatorward flow). In either case, the DWBC and EGIC transports for that occupation are anomalously small.

\subsection{Mixing}

It has been postulated that as the dense water cascades off the shelf to form the spill jet, mixing occurs with the ambient slope water that in turn results in cross-frontal exchange of mass and salt. To shed light on this shelf-basin mixing, plots of gradient Richardson Number $\left[N(x, z) / u_{z}(x, z)\right]^{2}$ for each occupation were computed from the buoyancy frequency $(\mathrm{N})$ and along-stream velocity $(\mathrm{u})$. The buoyancy frequency was calculated from the individual station data, with the depth range $(\Delta \mathrm{z})$ over which the density gradient was computed increasing with depth (in particular, $\Delta z$ varying from $10 \mathrm{~m}$ near the surface to $420 \mathrm{~m}$ at $1500 \mathrm{~m}$ ). The vertical gradient in alongstream velocity was obtained from the gridded geostrophic velocities (Figure 6). Vertical sections of Richardson Number were then constructed as described in Section 2. Experimentation using a variety of vertical ranges over which to evaluate $\mathrm{N}$ and $\mathrm{u}_{\mathrm{z}}(\mathrm{x}, \mathrm{z})$ revealed that the final values of Richardson Number were fairly insensitive to this choice, thus indicating that our conclusions are robust. 
In all four years, regions of small Richardson Number $(<1)$ are observed in the vicinity of the spill jet (with values locally falling below 0.25 ), suggesting that significant vertical mixing is occurring (Figure 7). In each occupation, the combination of relatively weak stratification and strong vertical shear in the jet produces conditions suitable for cross-frontal exchange.

In the two occupations where the spill jet is located closest to the shelfbreak (2001 and 2003), the mixing is limited in extent. The onshore movement of the EGIC front in these two years, and the relatively shallow isopycnal slope, are less favourable for the downslope export of cold, fresh shelf water into the Irminger Basin. By contrast, the Richardson Number in the latter two occupations (2004 and 2007) was less than 1 over most of the spill jet, due largely to the extremely strong vertical shear of the current. Evidence of exchange between the shelf and slope in the upper water column during the 2004 occupation was documented above, with two warm and salty lenses located onshore of the front and fresh shelf water present in the interior. It remains to be determined if such upper-layer cross-frontal exchange is related to the dense water spilling process. In the 2004 section both seemed to be prevalent.

While the modelling results of Magaldi et al. (in press) support the hypothesis that the spill jet is a region of enhanced mixing, the region of critical Richardson numbers is much larger in their numerical simulation. For instance, during the occupation of the 2003 vertical section, the model yields a region of Richardson Number less than 1 that covers the entire continental slope between $300 \mathrm{~m}$ and $1600 \mathrm{~m}$, while the observations suggest that the mixing is more limited. The reason for this discrepancy appears to be that the model has stronger vertical shear than the observations along most of the slope. The Richardson Number of the observations was relatively insensitive to the choice of vertical distance over which the vertical shear was computed. Magaldi et al. (in press) invoked a Richardson Number limit as part of their criteria for identifying the region of the spill jet 
for their transport calculations. We did not implement such a condition as it was clear from our velocity observations that the spill jet covered a wider area than that defined by the critical Richardson Numbers. Note in Figure 7 that there are critical values of the Richardson Number within the DSOW in each of the four occupations. This implies that the overflow water is actively mixing and homogenising at this latitude, which may at times involve entrainment of water from outside the high-velocity DWBC core (e.g. close to Station 31 in 2003).

\subsection{Temperature and Salinity Characteristics of the spill jet}

In the 2001 section, Pickart et al. (2005) observed that the spill jet occupied a portion of T/S space intermediate between pure Irminger Water and East Greenland Current Water. Using the abovenoted criteria for identifying the different components of the boundary current system (used in the transport calculations) we plotted the $\mathrm{T} / \mathrm{S}$ characteristics of the three components for each of the years (note that we have not attempted to separate the EGC and IC constituents). These are displayed in Figure 8. One sees that, as was the case in 2001, in 2003 the spill jet advected water within the T/S envelope of the EGIC water. As noted earlier, during both these occupations the hydrographic front of the EGIC is located onshore. This implies that as the shelf waters spill, they immediately encounter, and mix with, warm and salty Irminger Water which in turn would limit the density of the final product in the spill jet. However, as seen in the model simulations of Magaldi et al. (in press), at times the spill jet can advect water as dense as the DSOW. Our observations support this idea as well.

As seen in Figure 8c,d, in 2004 and 2007 a portion of the spill jet advected water within the density range of DSOW. During these two occupations the EGIC hydrographic front was located farther offshore, seaward of the shelfbreak. This suggests that waters cascading off the shelf were not as 
strongly mixed with the warm and salty Irminger Water during the formation of the spill jet. An additional conclusion could be that the 2004 and 2007 occupations sampled more recent spilling events than the previous two occupations. This is implied by the Richardson Number distributions (Figure 7). In particular, the region of critical Richardson Number was more extensive in 2004 and 2007, and the corresponding values smaller. This means that more active mixing was taking place during these two occupations, suggesting that the modification of the spilled shelf waters was just beginning.

The idea that the spill jet can advect water in the density range of DSOW implies that, at times, not all of the dense water in the Denmark Strait sill participates in the overflow process. This in turn suggests that a portion of the dense water in the strait sometimes remains on the shelf and subsequently cascades into the basin farther to the south. This scenario was postulated by Rudels et al. (2002) and also observed in the model simulations of Magaldi et al. (in press). Here we offer evidence that DSOW can indeed remain on the shelf as it passes through Denmark Strait. In October 2008 a hydrographic/velocity section was occupied across Denmark Strait near the latitude of the sill (see Figure 2 for the location of the section). At the time of the section, the deepest part of the strait (in particular the western side) was occupied by water denser than $\sigma_{\theta}=28.05 \mathrm{~kg} \mathrm{~m}^{-3}$, which coincided with the strongest equatorward velocities (Figure 9). This water likely formed the main overflow plume farther to the south. However, the section in Figure 9 also reveals that water denser than $\sigma_{\theta}=27.8 \mathrm{~kg} \mathrm{~m}^{-3}$ occupied a large portion of the East Greenland shelf (in fact, densities exceeding $\sigma_{\ominus}=27.9 \mathrm{~kg} \mathrm{~m}^{-3}$ were found on the shelf). Most of this water was flowing equatorward as well. It is clear that this water would have remained on the shelf and not contributed to the descending overflow plume. The section considered here is of course only a synoptic snapshot, but it demonstrates that, at times, there is dense water available for spilling south of Denmark Strait. In Figure 9, the transport of water with $\sigma_{\theta}>27.8 \mathrm{~kg} \mathrm{~m}^{-3}$ on the East Greenland shelf shoreward of 
$x=102 \mathrm{~km}$ (i.e. inshore of the $350 \mathrm{~m}$ isobath) was $1.1 \mathrm{~Sv}$.

\subsection{Vorticity Structure of the spill jet}

In order to investigate the stability properties of the spill jet, the Ertel potential vorticity (PV) was calculated for each of the sections following the methodology of Pickart et al. (2005). In the presentation below, the total PV is divided into a stretching term, a relative vorticity term that is dominated by the cross-stream gradient of alongstream velocity, and a tilting term that reflects horizontal density gradients (Hall, 1994):

$\mathrm{PV}=-f / \rho_{0} \partial \sigma_{d} / \partial z+1 / \rho_{0} \partial u / \partial y \partial \sigma_{d} \partial z-g / \rho_{0}^{2} f\left(\partial \sigma_{\delta} / \partial y\right)^{2}$

where $f$ is the Coriolis parameter, $\rho_{0}$ is the reference density $\left(1.031 \times 10^{3} \mathrm{~kg} \mathrm{~m}^{-3}\right)$ and $g$ is the gravitational acceleration. The total PV of the spill jet is an important diagnostic because it can be used to elucidate dynamical instability (Haine and Marshall, 1998; Charney and Stern, 1962), which could assist in determining the mechanisms by which mass and properties are fluxed in both directions across the front.

For each hydrographic section, the four PV terms (stretching, relative, tilting and total) were averaged over the depth range of the spill jet. These lateral distributions are presented in Figure 10. Stretching vorticity is most influential in setting the total PV, but relative and tilting vorticity are also important and the relative term can dominate within the spill jet (e.g. in 2003 and 2004). This is in contrast to most large-scale currents where the total PV is dictated by the stretching term. Total PV increases inshore of $x=70 \mathrm{~km}$ in all years, as a result of an increase in the stretching term. This is due to the fact that as one moves closer to the coast the depth of the water column decreases, hence 
the averaging is done over a region of stronger stratification.

These PV diagnostics reveal important insights on the dynamical stability of the spill jet. The relative vorticity term changes sign across the spill jet in each year (anticyclonic inshore and cyclonic offshore), reaching quite large values in some of the years (see below). We note that the relative vorticity term divided by the stretching term equals the non-dimensional relative vorticity $\zeta$ (i.e. the relative vorticity normalized by the Coriolis parameter $f$, which is a vorticity-based Rossby Number). When $\zeta$ is less than minus one, the absolute vorticity is negative and the flow is unstable to inertial overturning. This process causes horizontal exchange between fluid on the cyclonic and anticyclonic sides of the jet with a growth rate of $f / \sqrt{-(1+\zeta)}$ (Haine and Marshall, 1998). Using the curves in Figure 10 to compute $\zeta$, we find that it reaches approximately -1.3 in both 2003 and 2004 on the inshore flank of the spill jet. The timescale for inertial instability to grow in these cases is therefore around $2 / f$, or about $4 \mathrm{~h}$.

In the presence of stratification, inertial instability is modified so that modes which exchange along isobars grow more slowly than modes that mix along isopycnals. The growth rate is now given by $f / \sqrt{-(1+\zeta)+R i^{-1}}$ where $R i$ is the Richardson number (Haine and Marshall, 1998). The flow is susceptible to this so-called symmetric instability when $\zeta<-1+R i^{-1}$, or, equivalently, when the total PV is negative. These conditions apply to the spill jet as well in 2003 and 2004 (Figure 10). The 2004 case is particularly extreme. Figure 11 shows the vertical sections of the three PV components in that year (the relative and tilting terms are normalized by f), as well as the total PV. Recall that the spill jet was strongest in this realization $\left(>1.6 \mathrm{~m} \mathrm{~s}^{-1}\right.$, Figure 6$)$, and, as a result, $|\zeta|$ exceeds 2 on both sides of the jet (Figure 11a). The region of negative total PV is quite pronounced on the inshore flank of the current (Figure 11d). In fact, one sees that the overall distribution of total PV mimics that of $\zeta$ over the full extent of the spill jet. This is quite extraordinary, since the stretching 
dominates even strong currents like the Gulf Stream. From Figure 7 it is seen that the inshore flank of the spill jet has $R i$ in the range $0.5-1$. Hence the timescale for symmetric instability is around $0.7 / f$ to $0.9 / f$, or approximately $2 \mathrm{~h}$. These results suggest that fast instabilities can mix fluid in the region between the continental shelf and the spill jet core.

During the 2003 field program, an additional crossing of the shelfbreak was made roughly $50 \mathrm{~km}$ to the south of the repeat line (see Figure 2 for the location of the section). Figure 12a shows the alongstream velocity measured by the vessel-mounted ADCP, which reveals the presence of the spill jet near the upper continental slope with velocities exceeding $0.9 \mathrm{~m} \mathrm{~s}^{-1}$ (the ADCP observations did not extend deeper than about $400 \mathrm{~m}$ ). The CTD station occupied in the core of the current (station 52 in Figure 12a) revealed an $80 \mathrm{~m}$-thick layer that was neutrally stable to the accuracy of the calibrated CTD sensors (Figure 12b). This implies that as dense water cascades off the shelf, it may at times result in a gravitationally unstable water column that would rapidly adjust to form such vertically uniform regions within the jet.

The spill jet may also be susceptible to slower-growing instabilities. Specifically, the lateral gradient in total PV changes sign across the spill jet in every year, a necessary condition for baroclinic instability. This is largely due to the cross-stream distribution of relative vorticity, in particular the switch from strong cyclonic relative vorticity to anticyclonic (or near-zero) relative vorticity as one progresses onshore. The flow also meets a necessary condition for barotropic instability because the total PV exhibits extrema each year. These statements do not strictly apply in the presence of side boundaries, however, and the role of the continental slope is unclear. Unlike baroclinic and barotropic instability, symmetric instability does not involve any meanders in the direction of the flow. The PV condition for symmetric instability is also local in space, not global. For these reasons it is likely that symmetric instability is less strongly affected than baroclinic or barotropic instability 
by the presence of the continental slope.

\subsection{Double Diffusive Effects}

Due to the fact that cold, fresh shelf waters are spilled into, or adjacent to, warm, salty Irminger water, it is possible that double-diffusive effects might influence the cross-frontal mixing that occurs (Schmitt, 1994, 2003). Such mixing could play a role in the downstream evolution of the shelfbreak hydrographic front that occurs over a period of weeks. In particular, in the vicinity of Denmark Strait (i.e. where the repeat line is located) the front is thermally dominated, whereas near Cape Farewell $(750 \mathrm{~km}$ to the south) it is haline dominated. As seen in Figure 13, while there is colder, fresher water inshore of warmer, saltier water at both locations in the vicinity of the shelfbreak, at the northern line the lateral change in temperature determines the sign of the cross-frontal density change (dense to light), while at Cape Farewell the salinity dictates the lateral density gradient (light to dense). This in turn means that there is a change in the sense of the thermal wind shear between the two locations: bottom-intensified flow near Denmark Strait (Figure 5) and surface-intensified flow near Cape Farewell (e.g. Daniault et al., 2011).

Double diffusive processes, which arise from the difference between molecular diffusion coefficients of heat and salt, typically fall into two categories: those caused by salt fingering and those resulting from diffusive convection (Schmitt, 1994). In order to test for the presence of these processes at the spill jet line, density ratios were calculated for each $5 \mathrm{~m}$ bin at every CTD station for each year. In addition, the Turner angle, Tu, defined by $\mathrm{Tu}=\tan ^{-1}$ $(\alpha \partial \mathrm{T} / \partial \mathrm{z}-\beta \partial \mathrm{S} / \partial \mathrm{z}, \alpha \partial \mathrm{T} / \partial \mathrm{z}+\beta \partial \mathrm{S} / \partial \mathrm{z})$ where $\alpha$ and $\beta$ are the thermal expansion and haline contraction coefficients, was calculated as an indicator of double diffusion (Ruddick, 1983). 
If $-45^{\circ}<\mathrm{Tu}<45^{\circ}$, the water column is stable, while for $\mathrm{Tu}<-90^{\circ}$ or $\mathrm{Tu}>90^{\circ}$, the column is statically unstable. In the ranges $-90^{\circ}<\mathrm{Tu}<-45^{\circ}$ and $45^{\circ}<\mathrm{Tu}<90^{\circ}$, the water column is unstable to double diffusive processes, in the first instance to diffusive convection and in the latter case to salt fingering (Turner, 1973).

The conditions for double diffusion are met at most station positions throughout the four years. The calculated Turner angle sections suggest that much of the water column is unstable to salt fingering (Figure 14). Offshore of the shelfbreak there is clear evidence of cold and fresh intrusions (of thickness tens of metres) penetrating the warm and salty Irminger water. This is illustrated in Figure 15, which shows the $2 \mathrm{~m}$ vertical profiles of $\mathrm{T}$ and $\mathrm{S}$ from stations seaward of the shelfbreak in each of the realizations. One sees that there are numerous cold, fresh intrusions within the upper $700 \mathrm{~m}$ of the water column. The presence of these strong intrusions, along with the Turner angle values, suggests that salt fingering is quite active within the spill jet.

Thermohaline intrusions are commonly found at oceanic fronts and can be driven by the double-diffusive fluxes realized when the vertical gradients of temperature and salinity become intensified by fine-scale vertical shears (Ruddick, 2003). Alternating sites for fingering and diffusive convection are found at the top and bottom of each intrusion, leading to vertical flux divergences which modify the lateral density gradients in a manner that reinforces the intrusive motion. Fingers generally dominate the fluxes so that warm, salty intrusions lose more salt than heat and become lighter, while cold, fresh intrusions gain more salt than heat and become denser. The intrusions may be thought of as horizontal fingers. However, since the vertical flux of salt dominates over heat, the resultant lateral fluxes actually show a greater transport of heat than salt, since the temperature field is less "short- 
circuited" by the small-scale double diffusion (Ruddick and Richards, 2003).

As the off-shelf spilling first happens it may be that the fast growing inertial and symmetric instabilities discussed above dominate over slower-growing double diffusive intrusions. However, as time progresses, the stirring produced by these rapid processes will undoubtedly create numerous sites where the micro-scale double-diffusive instabilities will act on the intensified vertical gradients and produce differential transport of heat and salt as described above. Previous observations have shown that double-diffusive fluxes will be large when the gradients are favourable (Schmitt et al, 2005; Schmitt and Georgi, 1982). While we cannot claim that double diffusion is creating the intrusions, we can say with confidence that it is an active mixing agent helping to dissipate the variance created by the horizontal stirring processes in this region.

As noted above (Figure 13), there is a fundamental difference in the cross-frontal density structure between $65^{\circ} \mathrm{N}$ and Cape Farewell. This is quantified in Figure 16, which displays the lateral variation in temperature, salinity, and density averaged vertically within the subsurface boxes of Figure 13. At the spill jet line the plot includes the variation in density holding the salinity constant, while for the Cape Farewell section the same has been done keeping the temperature constant. One sees that at the northern line the density variation is predominantly due to temperature, whereas at Cape Farewell the salinity dominates. The main reason for this change is that, progressing southward, the lateral temperature gradient weakens significantly more than the salinity gradient. Note that the temperature change across the front at the spill jet line is approximately $3.5^{\circ} \mathrm{C}$, while to the south it is less than $0.5^{\circ} \mathrm{C}$. As described above, the net effect of the double-diffusive intrusions is to enhance the lateral flux of temperature over salinity, hence this will act to smooth out the temperature 
front more effectively than the salinity front, consistent with the observations. Therefore, double-diffusive mixing during the spilling process - and farther downstream as the water masses adjust - might help to explain the change in density structure of the shelfbreak front between Denmark Strait and Cape Farewell.

\section{Conclusions and Discussion}

Results from hydrographic sections collected in four different summer seasons have confirmed that the East Greenland spill jet is a permanent feature of the boundary current system south of Denmark Strait, at least in summer (mooring data from this location indicate that the spill jet is a year-round feature (Harden and Pickart, 2011)) The jet is narrow (on the order of $15 \mathrm{~km}$ ), bottom-intensified, reaches peak velocities of up to $1.6 \mathrm{~m} \mathrm{~s}^{-1}$, and has very strong lateral velocity shear. The spill jet is also responsible for a significant fraction of the total boundary current transport at this location, on the same order as the DWBC. This is in agreement with the modelling results of Magaldi et al. (in press). The lateral position of the spill jet varies between the outer shelf and roughly the $1000 \mathrm{~m}$ isobath on the continental slope. Its $\mathrm{T} / \mathrm{S}$ properties change in time, comprising different admixtures of East Greenland Current Water, Irminger Water, and DSOW. The variability in location, strength, mixing, and $\mathrm{T} / \mathrm{S}$ properties of the spill jet appear to be linked to the proximity of the upper-layer EGIC hydrographic front to the shelf edge, and/or the temporal stage of the spilling process. In the two occupations where the EGIC front was situated near the shelfbreak, the spill jet was confined to the outer shelf and upper slope, the transport of the jet was smaller, and mixing within the jet was limited. By contrast, when the hydrographic front was located seaward of the shelfbreak, the spill jet extended farther downslope, its transport was enhanced, the jet advected denser water - as dense as DSOW - and was subject to more active mixing. 
Our analysis suggests that the spill jet is subject to a number of different instability mechanisms. Examination of the terms contributing to the potential vorticity implies that symmetric instability can cause mixing on the shoreward side of the spill jet. This instability arises from very strong vertical vorticity causing the absolute vorticity, and the Ertel PV, to become negative. This process grows with a timescale of about 2-4 h and mixes momentum along isopycnals. Additionally, the spilling of dense water off the shelf may at times cause the water column to be gravitationally unstable, which also leads to quick adjustment of the current via mixing. The jet may be susceptible to slowergrowing baroclinic and barotropic instability as well, although the presence of the continental slope in these processes is unclear. It is also likely that double diffusive mixing occurs due to the influx of cold, fresh shelf water into the warm, salty Irminger water offshore, which in turn may alter the downstream structure of the shelfbreak front and current.

Owing to the limited scope of our observations, it is difficult to assess the nature of the observed spill jet in the context of the modelling study of Magaldi et al. (in press). However, it is intriguing that the largest individual spill jet transport occurred in 2004 when the hydrographic front was displaced farthest offshore. This is consistent with the Type 2 spilling mechanism proposed by Magaldi et al. (in press). In this scenario, shelf water is drawn offshore in concert with a meander of the EGIC front, which in turn is associated with the passage of a bolus of DSOW at depth. This process allows large volumes of spill jet water to move down the slope. Additional observations and modelling will be necessary to investigate further the mechanisms leading to the off-shelf spilling and establishment of the spill jet.

Our findings have important implications for understanding the fate and distribution of northernorigin waters as they penetrate the sub-polar North Atlantic south of Denmark Strait. It is evident that lateral exchange associated with the cascading of dense water off the shelf is important in setting 
the final transport and properties of the currents along the continental slope of the Irminger Sea. Both conditions on the shelf and the mixing processes seaward of the shelf appear to play an important role. This raises the possibility that a change in the composition of the shelf water flowing through Denmark Strait in response to enhanced Arctic freshwater discharge or changes in atmospheric forcing could in turn influence the intermediate, and perhaps deep, limb of the meridional overturning circulation. Understanding the dynamics of this region will thus be important for predicting future changes in the North Atlantic climate system.

\section{Appendix A: Calculation of Transport Errors}

The most important source of error in our estimation of transport is uncertainty in the reference velocity provided by the vessel-mounted ADCPs. ADCP error is divided into measurement error (which comprises both instrument and calibration errors) and uncertainty associated with inaccurate bathymetry in the OSU tidal model. Flow through 'bottom triangles' constituted a negligible error due to the very close station spacing. The ADCP errors were estimated using similar methods to those employed by Våge et al. (2011).

To calculate instrument error, the standard deviation of single ping on-station measurements averaged into five-minute ensembles was evaluated. Values of between 1 and $2 \mathrm{~cm} \mathrm{~s}^{-1}$ were obtained for all four sections. Calibration errors as a result of transducer misalignment are routinely calculated in the data-processing stage and yielded values of between 0.2 and $0.4 \mathrm{~cm} \mathrm{~s}^{-1}$. Total measurement error was thus conservatively estimated at $3 \mathrm{~cm} \mathrm{~s}$. Differences between observed and model bottom depths were calculated for each section and the depth-scaled difference in tidal transport was used as an indicator of the size of the detiding error at each station location. While this scaling does not provide a perfect error estimate (as the initial computation of tidal transport by the model uses model 
depth as an input), experience from a number of cruises has shown that this method is a reliable indicator of detiding error. Across most of the spill jet section, the detiding error is less than $1 \mathrm{~cm} \mathrm{~s}^{-1}$ (tidal velocities in this location are weak), though a small ( $5 \mathrm{~km}$ wide) region of elevated error is observed close to the shelf edge. As a result, a conservative tidal model error estimate of $2 \mathrm{~cm} \mathrm{~s}^{-1}$ was used across the section.

The total velocity uncertainty was determined as the root of the sum of squares of the instrument and tidal-model errors, thus yielding a total error of $3.6 \mathrm{~cm} \mathrm{~s}^{-1}$. To give a conservative total transport uncertainty, it was not assumed that the error was uncorrelated across each section. The total error for each portion of the boundary current was computed and added as an error bar to Table 1 . The uncertainty on the mean transports at the bottom of Table 1 was calculated from the maximum and minimum possible transport from each component of the boundary current.

\section{Appendix B: Calculation of Boundary Current Transports}

Identifying appropriate lateral and density boundaries for each component of the boundary current is important to obtaining reliable transport estimates. Several guiding criteria were used to separate the EGIC, spill jet and DWBC components in each section.

1. The spill jet and DWBC have bottom-intensified flow, while the EGIC is identified by a nearsurface transport maximum.

2. The spill jet and DWBC are separated by a velocity minimum, which varies in magnitude from

$<0.05 \mathrm{~m} \mathrm{~s}^{-1}$ in 2003 to $>0.2 \mathrm{~m} \mathrm{~s}^{-1}$ in 2001 and 2007 .

3. The spill jet is associated with a maximum in lateral density gradient within $\sim 10 \mathrm{~km}$ of the shelf- 
edge.

4. The DWBC is generally better ventilated than the spill jet (note: oxygen data were not available for 2007, so this criterion could not be used in that year).

5. All of the equatorward transport between $56 \mathrm{~km}$ and $102 \mathrm{~km}$ is assigned to one of the three components.

The use of these criteria dictates the choice of boundaries detailed in Table 1. More detailed discussions for individual years are given below.

2001

The upper density limit chosen for the spill jet $\left(\sigma_{\theta}=27.55\right)$ and its offshore lateral boundary $(76 \mathrm{~km})$ successfully separate the bottom-intensified flow associated with the strong isopycnal slope from the surface-intensified EGIC (criteria 1 and 3). Moreover, the offshore boundary is located at the velocity minimum that separates the spill jet and DWBC (criterion 2). The upper density limit of the DWBC $\left(\sigma_{\ominus}=27.7\right)$ is selected as it coincides with the upper limit of the deep bottom-intensified flow and is relatively well-ventilated up to this level (Pickart et al., 2005, Figure 7). The remaining surface-intensified flow is classed as EGIC (criteria 1 and 5). Transport values using the different boundaries employed by Pickart et al. (2005) are given in brackets in Table 1.

The upper-bounding spill jet isopycnal of $\sigma_{\theta}=27.45$ ensures that the bottom-intensified flow on the outer shelf is classed as spill jet (criterion 1), while the lateral boundaries (56 km and $72 \mathrm{~km}$ ) successfully separate the flow by its velocity minimum from the DWBC (criterion 2) and from the 
surface-intensified velocity core near Station 34 (criterion 1). The choice of $\sigma_{\theta}=27.7$ as the upperbounding isopycnal for the DWBC was made primarily with reference to the oxygen field (not shown), which reveals more well-ventilated water (values exceeding $6.7 \mathrm{ml} \mathrm{l}^{-1}$ ) at densities larger than this value (criterion 4). The inclusion of the upper part of the bottom-intensified flow (between Stations 33 and 32 in Figure 6b) as part of the EGIC, while appearing to violate criterion 1, is justified by the low oxygen and density of this water mass, which is more akin to EGIC than to the DWBC.

2004

In this year, use of $\sigma_{\theta}=27.55$ as the upper-bounding isopycnal for the spill jet more successfully separates the bottom-intensified spill jet from the surface-intensified EGIC (criterion 1). Furthermore, the lateral spill jet boundaries $(66 \mathrm{~km}$ and $82 \mathrm{~km})$ clearly encompass the region of maximum isopycnal slope (criterion 3), while also separating the spill jet by a velocity minimum from the DWBC (criterion 2). Elevated oxygen levels (over $6.7 \mathrm{ml} \mathrm{l}^{-1}$ ) are again observed at levels denser than $\sigma_{\theta}=27.7$ (criterion 4). The remainder of the region between $56 \mathrm{~km}$ and $102 \mathrm{~km}$, which exhibits predominantly surface-intensified flow, is assigned as EGIC (criterion 5).

2007

As in 2001 and 2004, $\sigma_{0}=27.55$ is the most appropriate isopycnal to separate the surface-intensified EGIC from the bottom-intensified spill jet (criterion 1). Use of $80 \mathrm{~km}$ as the offshore limit of the spill jet both ensures that the spill jet transport covers the region of maximum isopycnal slope (criterion 3 ) and is separated from the DWBC by a velocity minimum (criterion 2). No oxygen data were taken during the 2007 occupation, but the $\sigma_{\theta}=27.7$ isopycnal is used both to ensure 
consistency with the other years and because it encompasses most of the high-velocity core associated with the DWBC plume. The remainder of the section is assigned to the EGIC as it incorporates the near-surface maximum close to $70 \mathrm{~km}$ along the section (criterion 5).

\section{Acknowledgements}

The authors wish to thank Theresa McKee, Daniel Torres, and Paula Fratantoni for their help in processing the CTD and vessel-mounted ADCP data. Kjetil Våge assisted in the collection of the data. Insightful discussions with Marcello Magaldi and Wilken-Jon von Appen are acknowledged. This study was funded by National Science Foundation Grant OCE-0722694. Further funding was provided by the University of Southampton-Woods Hole Oceanographic Institution Exchange Scheme and by a Rupert Ford Award from the Royal Meteorological Society of the United Kingdom.

\section{References}

Bacon, S., 1997. Circulation and fluxes in the North Atlantic between Greenland and Ireland. J. Phys. Oceanogr. 27, 1420-1435.

Bacon, S., Reverdin, G. Rigor, I.G., Snaith, H.M., 2002. A freshwater jet on the east Greenland shelf. J. Geophys. Res. 107, 3068, doi:10.1029/2001JC000935.

Blindheim, J., 1968. Hydrographic investigations in the Irminger Sea in the years 1954-1964. FiskDir. Skr. Ser. HavUnders. 14, 72-97. 
Charney, J.G., Stern, M.E., 1962. On the stability of internal baroclinic jets in a rotating atmosphere. J. Atmos. Sci. 19, 159-172.

Daniault, N., Lherminier, P., Mercier, H., 2011. Circulation and transport at the southeast tip of Greenland. J. Phys. Oceanogr. 41, 437-457.

Defant, A., 1930. Bericht über die ozeanographischen Untersuchungen des Vermessungsschiffes "Meteor" in der Dänemarkstrasse und in der Imingersee. Preuss. Akad. Wiss. Sitz. Phys. Math. Klasse XVI, 230-235.

Dickson, R.R., Brown, J., 1994. The production of North Atlantic deep water: Sources, rates, and pathways. J. Geophys. Res. 99, 12319-12341.

Dietrich, G., 1964. Oceanic polar front survey in the North Atlantic. Res. Geophys. 2, 291-308.

Egbert, G.D., Bennett, A.F., Foreman, M.G.G, 1994. TOPEX/POSEIDON tides estimated using a global inverse model. J. Geophys. Res. 99, 24821-24852.

Egbert, G.D., Erofeeva, S. Y., 2002. Efficient inverse modeling of barotropic ocean tides. J. Atmos. Oceanic Technol. 19, 183-204.

Fiedler, A., 2003. Om Irminger Havets og Irminger Strommens navn. Sovoernsorientering 1, 1-3.

Fratantoni, D.M., Pickart, R.S., Torres, D.J., Scotti A., 2001. Mean structure and dynamics of the shelfbreak jet in the Middle Atlantic Bight during fall and winter. J. Phys. Oceanogr. 31, 2135-2156. 
Georgi, D.T., Schmitt, R.W., 1983. Fine and microstructure observations on a hydrographic section from the Azores to the Flemish Cap. J. Phys. Oceanogr. 13, 632-647.

Haine, T.W.N., Marshall, J.C., 1998. Gravitational, symmetric and baroclinic instability of the ocean mixed layer. J. Phys. Oceanogr. 28, 634-658.

Haine, T.W.N., Zhang, S., Moore, G.W.K., Renfrew, I.A, 2009. On the impact of high-resolution, high-frequency meteorological forcing on Denmark Strait ocean circulation. Q. J. R. Meteorol. Soc. 135, 2067-2085, DOI: 10.1002/qj.505.

Hall, M.M., 1994. Synthesizing the Gulf Stream thermal structure from XBT data. J. Phys. Oceanogr. 24, 2278-2287.

Harden, B.E. and R.S. Pickart, 2011. Cross-slope transport of dense water from the East Greenland shelf and the role of barrier winds. Proceedings of the 11th AMS conference on Polar Meteorology and Oceanography.

Lee, A.J., 1968. NORWESTLANT Surveys: Physical Oceanography. ICNAF Special Publication, Environmental Surveys Vol. 7, Part I, 31-54.

Magaldi, M., Haine, T.W.N., Pickart, R.S., 2011. On the nature and variability of the East Greenland Spill Jet: A case study in summer 2003. J. Phys. Oceanogr., in press.

Malmberg, S-A., Gade, H.G., Sweers, H.E., 1967. Report on the second joint Icelandic-Norwegian 
expedition to the area between Iceland and Greenland in August-September 1965. NATO Subcommittee on Oceanographic Research Tech. Rep. 41, Irminger Sea Project, 44 pp.

Nof, D., 1983. The translation of isolated cold eddies on a sloping bottom. Deep-Sea Res. A. 30 (2), $171-182$.

Pickart, R.S., Torres, D.J., Fratantoni, P.S., 2005. The East Greenland Spill Jet. J. Phys. Oceanogr. $35,1037-1053$

Pollard, R., Read, J.F., Holliday, N.P., Leach, H., 2004. Water masses and circulation pathways through the Iceland Basin during Vivaldi 1996. J. Geophys. Res. 109, C04004, doi:10.1029/ 2003JC002067.

Ruddick, B., 1983. A practical indicator of the stability of the water column to double-diffusive activity. Deep-Sea Res. 30 (10A), 1105-1107.

Ruddick, B., 2003. Laboratory studies of interleaving. Prog. Oceanogr. 56 (3-4), 529-547.

Ruddick, B., Richards, K., 2003. Oceanic thermohaline intrusions: observations. Prog. Oceanogr. 56 $(3-4), 499-527$.

Rudels, B., Eriksson, P., Gronvall, H., Hietala, R., Launiainen, J., 1999. Hydrographic observations in Denmark Strait in fall 1997, and their implications for the entrainment into the overflow plume. Geophys. Res. Lett. 26, 1325-1328. 
Rudels, B., Fahrbach, E., Meincke, J., Budeus, G., Eriksson, P., 2002. The East Greenland Current and its contribution to the Denmark Strait Overflow. ICES J. Mar Sci. 59, 1133-1154.

Schmitt, R.W., 1994. Double diffusion in oceanography. Ann. Rev. Fluid Mech. 26, 255-285.

Schmitt, R.W., 2003. Observational and laboratory insights into salt finger convection. Prog. Oceanogr. 56 (3-4), 419-433.

Schmitt, R.W., Georgi, D.T., 1982. Finestructure and microstructure in the North Atlantic Current. J. Mar Res. Supplement to 40, 659-705.

Schmitt, R. W., J. R. Ledwell, E. T. Montgomery K. L. Polzin, and J. M. Toole, 2005. Enhanced Diapycnal Mixing by Salt Fingers in the Thermocline of the Tropical Atlantic. Science, 308 (5722), 685-688.

Spall, M.A., Price, J.F., 1995. Mesoscale variability in Denmark Strait: The PV Outflow Hypothesis. J. Phys. Oceanogr. 28, 1598-1623.

Sutherland, D., Pickart, R.S., 2008. The East Greenland Coastal Current: Structure, variability, and forcing. Prog. Oceanogr. 78, 58-77.

Turner, J.S., 1973. Buoyancy effects in fluids. Cambridge University Press.

Våge, K., Pickart, R.S., Spall, M.A., Valdimarsson, H., Jonsson, S., Torres, D.J., Østerhus, S., Eldevik, 2011. Significant role of the North Icelandic Jet in the formation of Denmark Strait 
overflow water. Nature Geosci. 4, 723-727. 


\begin{tabular}{|c|c|c|c|}
\hline Year & & Boundaries of domain used & $\begin{array}{l}\text { Equatorward } \\
\text { transport }(S v)\end{array}$ \\
\hline \multirow[t]{5}{*}{2001} & DWBC & $76-102 \mathrm{~km}, \sigma_{\theta}>27.7$ & $7.1 \pm 0.7(6.0)$ \\
\hline & & $\begin{array}{l}\sigma_{\theta}>27.8 \text { (as in Dickson and } \\
\text { Brown, 1994) }\end{array}$ & $2.0 \pm 0.2(3.4)$ \\
\hline & spill jet & $56-76 \mathrm{~km}, \sigma_{\theta}>27.55$ & $2.7 \pm 0.2(1.9)$ \\
\hline & EGIC & $56-76 \mathrm{~km}, \sigma_{\theta}<27.55$ & $8.2 \pm 0.9(11.7)$ \\
\hline & & $76-102 \mathrm{~km}, \sigma_{\theta}<27.7$ & \\
\hline \multirow[t]{5}{*}{2003} & DWBC & $78-102 \mathrm{~km}, \sigma_{\theta}>27.7$ & $5.8 \pm 0.5$ \\
\hline & & $\sigma_{\theta}>27.8$ (as in Dickson and & \\
\hline & & Brown, 1994) & $2.9 \pm 0.2$ \\
\hline & spill jet & $56-72 \mathrm{~km}, \sigma_{\theta}>27.45$ & $2.2 \pm 0.2$ \\
\hline & EGIC & $\begin{array}{l}56-72 \mathrm{~km}, \sigma_{\theta}<27.45 \\
72-78 \mathrm{~km}, \\
78-102 \mathrm{~km}, \sigma_{\theta}<27.7\end{array}$ & $10.7 \pm 1.0$ \\
\hline \multirow[t]{4}{*}{2004} & DWBC & $82-102 \mathrm{~km}, \sigma_{\theta}>27.7$ & $5.6 \pm 0.5$ \\
\hline & & $\begin{array}{l}\sigma_{\theta}>27.8 \text { (as in Dickson and } \\
\text { Brown, 1994) }\end{array}$ & $4.2 \pm 0.4$ \\
\hline & spill jet & $\begin{array}{l}66-82 \mathrm{~km}, \\
27.55<\sigma_{\ominus}<27.85\end{array}$ & $10.4 \pm 0.4$ \\
\hline & EGIC & $\begin{array}{l}56-66 \mathrm{~km}, \text { full depth; } \\
66-82 \mathrm{~km}, \sigma_{\theta}<27.55 \\
82-102 \mathrm{~km}, \sigma_{\theta}<27.7\end{array}$ & $5.0 \pm 0.8$ \\
\hline \multirow[t]{4}{*}{2007} & DWBC & $80-102 \mathrm{~km}, \sigma_{\theta}>27.7$ & $1.6 \pm 0.3$ \\
\hline & & $\begin{array}{l}\sigma_{\theta}>27.8 \text { (as in Dickson and } \\
\text { Brown, 1994) }\end{array}$ & $0.9 \pm 0.2$ \\
\hline & spill jet & $56-80 \mathrm{~km}, \sigma_{\theta}>27.55$ & $4.6 \pm 0.3$ \\
\hline & EGIC & $\begin{array}{l}56-80 \mathrm{~km}, \sigma_{\theta}<27.55 \\
80-102 \mathrm{~km}, \sigma_{\theta}<27.7\end{array}$ & $3.1 \pm 0.7$ \\
\hline \multirow{4}{*}{$\begin{array}{l}\text { Mean } \pm \\
\text { (standard } \\
\text { error) }\end{array}$} & DWBC & & $4.9 \pm 0.5$ (s.e. 1.4$)$ \\
\hline & spill jet & & $5.0 \pm 0.3$ (s.e. 2.2) \\
\hline & EGIC & & $6.8 \pm 0.9$ (s.e. 1.9) \\
\hline & $\begin{array}{l}\text { Total } \\
\text { equatorward } \\
\text { transport }\end{array}$ & & $16.9 \pm 1.5$ (s.e. 3.0$)$ \\
\hline
\end{tabular}

Table 1: Total equatorward transport (in Sv) for the three components of the East Greenland boundary current system for the years 2001, 2003, 2004 and 2007. The error values given are calculated from the instrumental and detiding error of the ADCP. The mean of the four sections is also given, with both an ADCP-based error and a standard error. For comparison, the values from Pickart et al. (2005) for 2001, using alternative boundaries, are given in parentheses. 


\section{Figure Captions}

Figure 1: Schematic representation of the boundary currents in the Irminger Sea (after Pickart et al., 2005). Red and blue lines denote warm and cold upper layer currents, respectively. The flow of dense water is indicated by the grey lines, and water cascading off the shelf to form the spill jet is indicated by the purple arrows. The abbreviations are: EGC $=$ East Greenland Current; IC = Irminger Current; EGCC $=$ East Greenland Coastal Current; DWBC $=$ Deep Western Boundary Current.

Figure 2: (a) Locations of the hydrographic stations used in the study (indicated by crosses). Most of the analysis is focused on the repeat sections near $65^{\circ} \mathrm{N}$. The rectangle denotes the area of detail in (b) showing the vicinity of Denmark Strait. (b) Detailed view of the sections at and near the spill jet line and the section near the Denmark Strait sill (see the key).

Figure 3: Vertical sections of salinity and potential temperature $\left(\right.$ in $\left.{ }^{\circ} \mathrm{C}\right)$ along the spill jet section: (a), (c), (e) and (g) display potential temperature in 2001, 2003, 2004 and 2007 respectively, while (b), (d) and (f) and (h) show salinity in those years. $\sigma_{\theta}$ surfaces in $\mathrm{kg} \mathrm{m}^{-3}$ are overlaid and station numbers are given for each panel.

Figure 4: (a) Mean potential temperature and (b) mean salinity for the four sections, with $\sigma_{\theta}$ surfaces in $\mathrm{kg} \mathrm{m}^{-3}$ overlaid. Note the shorter $\mathrm{x}$-axis than in Figure 3.

Figure 5: Mean absolute geostrophic velocity (in $\mathrm{cm} \mathrm{s}^{-1}$ ) from the four spill jet crossings. Positive velocity is equatorwards. $\sigma_{\theta}$ surfaces in $\mathrm{kg} \mathrm{m}^{-3}$ are overlaid. 
Figure 6: Absolute geostrophic velocity (in $\mathrm{cm} \mathrm{s}^{-1}$ ) for each year: (a) 2001; (b) 2003; (c) 2004 and (d) 2007. Note that the extremely high spill jet velocities in 2004 necessitate a different colour bar in that year. Positive velocities are equatorward. $\sigma_{\theta}$ surfaces in $\mathrm{kg} \mathrm{m}^{-3}$ are overlaid and station numbers are given for each panel. The thin white lines mark the limits of the three components of the boundary current invoked for the transport calculations (see Appendix B).

Figure 7: Gradient Richardson Number sections for (a) 2001; (b) 2003; (c) 2004 and (d) 2007. Areas in the darkest shade of red have values of less than $1 . \sigma_{\theta}$ surfaces in $\mathrm{kg} \mathrm{m}^{-3}$ are overlaid.

Figure 8: $\theta / \mathrm{S}$ diagram of the boundary current sections for the years (a) 2001; (b) 2003; (c) 2004 and (d) 2007 respectively, with the three separate components of the boundary current, as defined in Table 1, colour-coded accordingly. Density contours are plotted.

Figure 9: Vertical sections across the Denmark Strait sill in 2008 (see Figure 2 for the location of the section). The top panel shows potential temperature (colour, ${ }^{\circ} \mathrm{C}$ ) overlaid by potential density (contours, $\mathrm{kg} \mathrm{m}^{-3}$ ). The lower panel shows absolute geostrophic velocity (colour, $\mathrm{cm} \mathrm{s}^{-1}$ ) overlain by potential density (equatorward is positive). The $\sigma_{\theta}=27.8 \mathrm{~kg} \mathrm{~m}^{-3}$ contour is highlighted. Station positions are marked along the top.

Figure 10: Total potential vorticity (PV) budget in the depth range of the spill jet, decomposed into the three terms defined in Equation 1. The individual panels show the PV for (a) 2001 (averaged between $200 \mathrm{~m}$ and $850 \mathrm{~m}$ ); (b) 2003 (averaged between $100 \mathrm{~m}$ and $700 \mathrm{~m}$ ); (c) 2004 (averaged between $150 \mathrm{~m}$ and $1100 \mathrm{~m}$ ) and (d) 2007 (averaged between $200 \mathrm{~m}$ and $1000 \mathrm{~m}$ ). The location of the spill jet is denoted by grey shading in each 
realization.

Figure 11: Vertical sections of components of potential vorticity for the 2004 crossing. The individual panels show (a) Relative vorticity divided by stretching vorticity (the nondimensional $\zeta$ ); (b) Stretching vorticity; (c) Tilting vorticity divided by stretching vorticity and (d) Total Ertel PV. Station locations are indicated along the top. The zero value is contoured as a thick black line.

Figure 12: (a) Alongstream velocity (colour, $\mathrm{cm} \mathrm{s}^{-1}$ ) measured by the shipboard ADCP in 2003 at a section approximately $50 \mathrm{~km}$ south of the repeat spill jet line (see Figure 2 for location). Equatorward velocities are positive. The potential density is overlaid (contours, $\mathrm{kg} \mathrm{m}^{-3}$ ). Station locations/numbers are indicated along the top. The thick black rectangle denotes the portion of the water column that was neutrally stable at station 52. An additional density contour $\left(\sigma_{\theta}=27.557 \mathrm{~kg} \mathrm{~m}^{-3}\right)$ is shown near this region. (b) Vertical profiles of potential temperature, salinity, and potential density at station 52 . The grey shading denotes the layer that is neutrally stable (corresponding to the thick black rectangle in (a).

Figure 13: Vertical sections of the shelfbreak hydrographic front at $65^{\circ} \mathrm{N}$ (spill jet line in 2001 , top row) compared with $60^{\circ} \mathrm{N}$ (near Cape Farewell in 2001, bottom row). The left hand panels are potential temperature (colour, ${ }^{\circ} \mathrm{C}$ ) overlaid by potential density (contours, $\mathrm{kg} \mathrm{m}^{-3}$ ), and the right hand panels are salinity (colour) overlain by potential density. Station positions are marked along the top. The rectangles in each panel mark the region over which the lateral profiles were constructed in Figure 15.

Figure 14: Turner angles from each CTD station (in degrees) along the spill jet section. Red 
areas denote regions subject to salt fingering $\left(45^{\circ}<\mathrm{Tu}<90^{\circ}\right)$, blue areas denote regions susceptible to diffusive convection $\left(-90^{\circ}<\mathrm{Tu}<-45^{\circ}\right)$ and black areas denote regions of possible static instability $\left(\mathrm{Tu}<-90^{\circ}\right.$ or $\left.\mathrm{Tu}>90^{\circ}\right)$.

Figure 15: Potential temperature $\left({ }^{\circ} \mathrm{C}\right.$, red) and salinity (blue) for stations seaward of the shelfbreak close to the spill jet. Cold and fresh intrusions within warmer and saltier Irminger water - indicative of double diffusive convection - are denoted with horizontal dashed lines. The individual panels show (a) Station 21 in 2001; (b) Station 36 in 2003; (c) Station 68 in 2004 and (d) Station 65 in 2007. Note the different scales between the panels.

Figure 16: Average lateral profiles of potential temperature, salinity, and potential density (blue curves) across the shelfbreak front at $65^{\circ} \mathrm{N}$ (spill jet line, left-hand panels) versus $60^{\circ} \mathrm{N}$ (near Cape Farewell, right-hand panels) in 2001. The vertical axes are the same for each pair of plots to facilitate comparison. In the left-hand panel of the bottom row the red dashed curve is the density computed with salinity held constant $\left(65^{\circ} \mathrm{N}\right)$. In the right-hand panel of the bottom row the red dashed curve is the density with temperature held constant $\left(60^{\circ} \mathrm{N}\right)$. The regions over which the profiles were computed are marked by the rectangles in Figure 13. The boxes where chosen so as to cross the hydographic front within the same depth range at the two locations. 


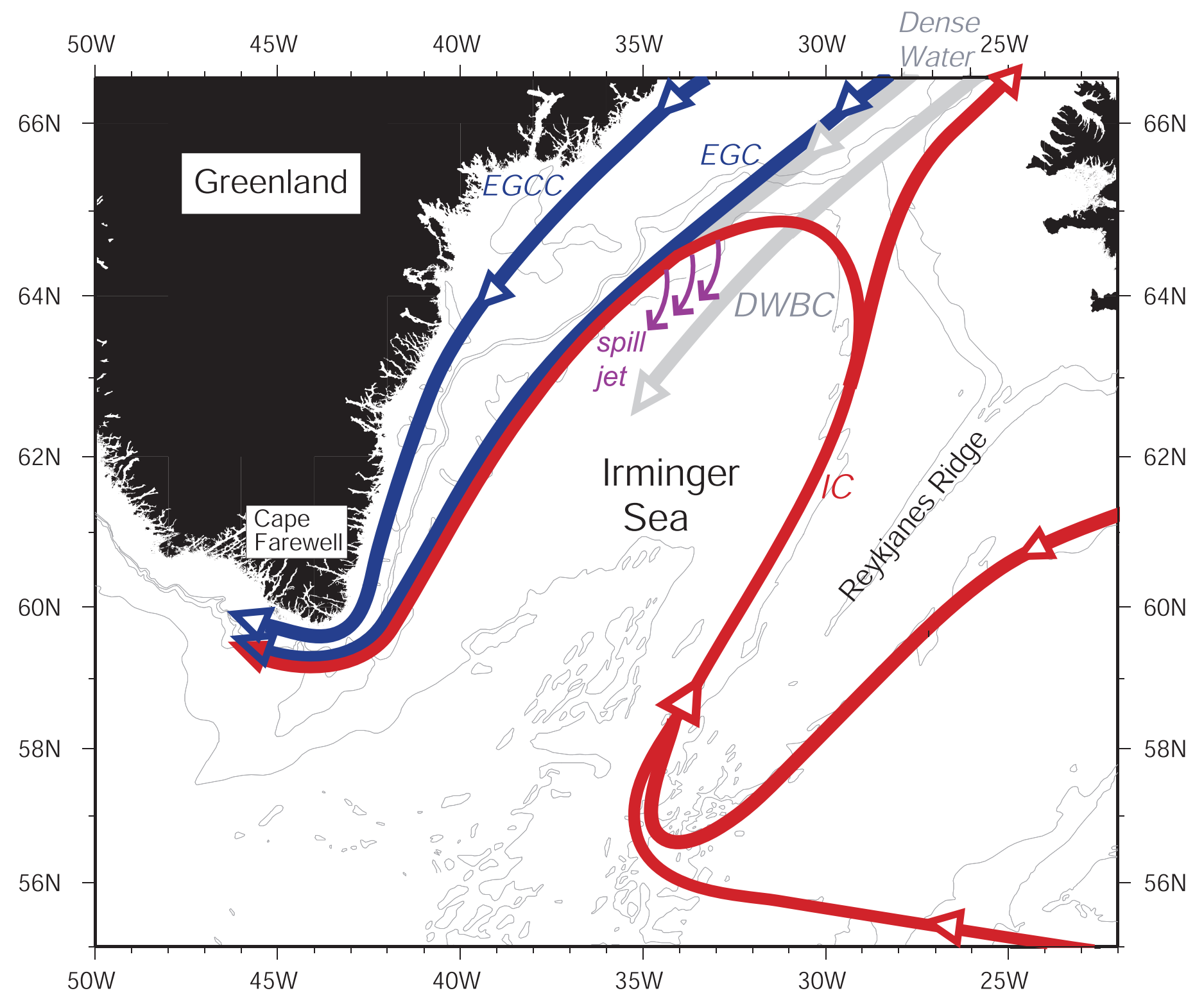


Click here to download Figure: fig_2a.eps

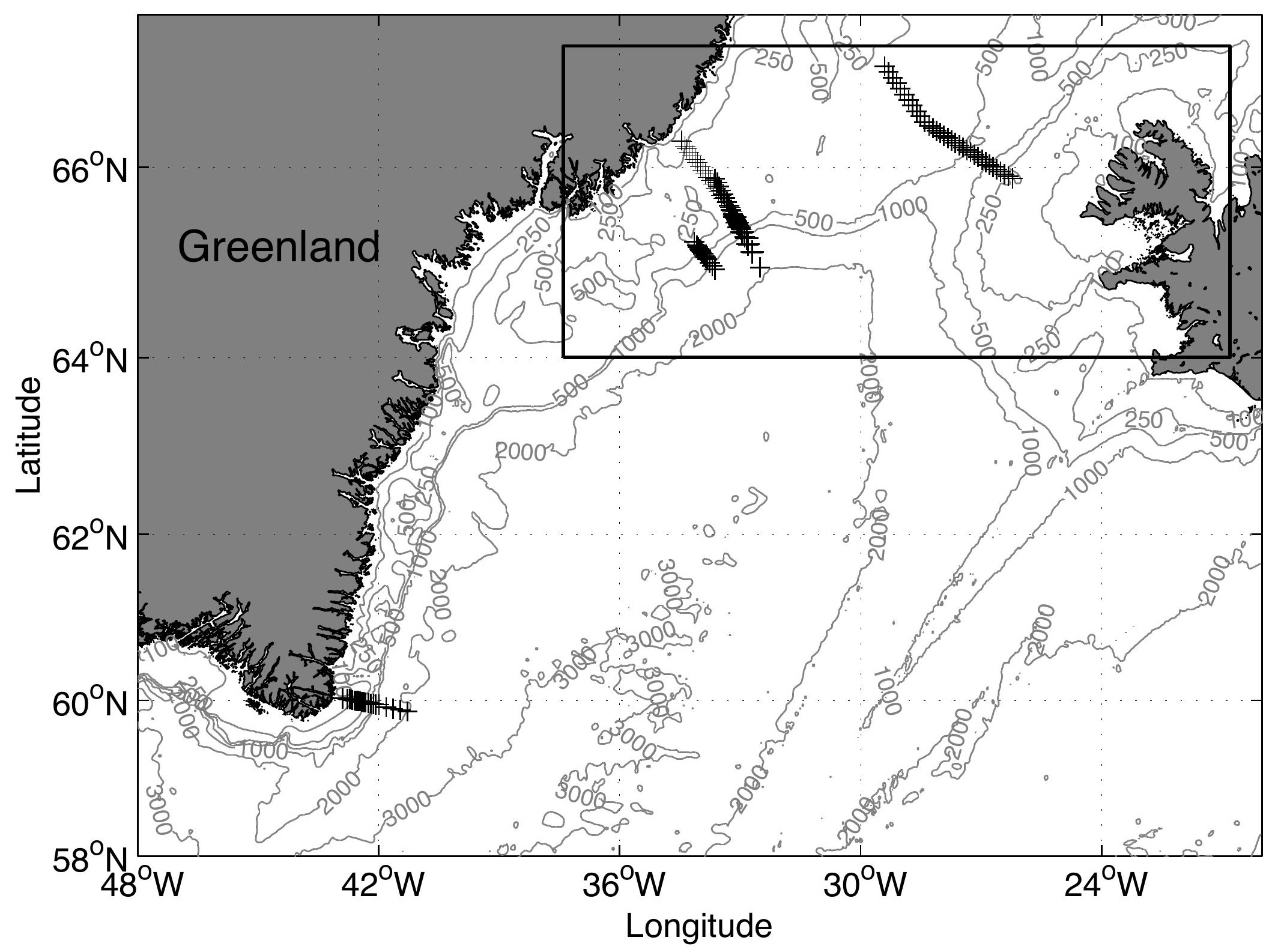




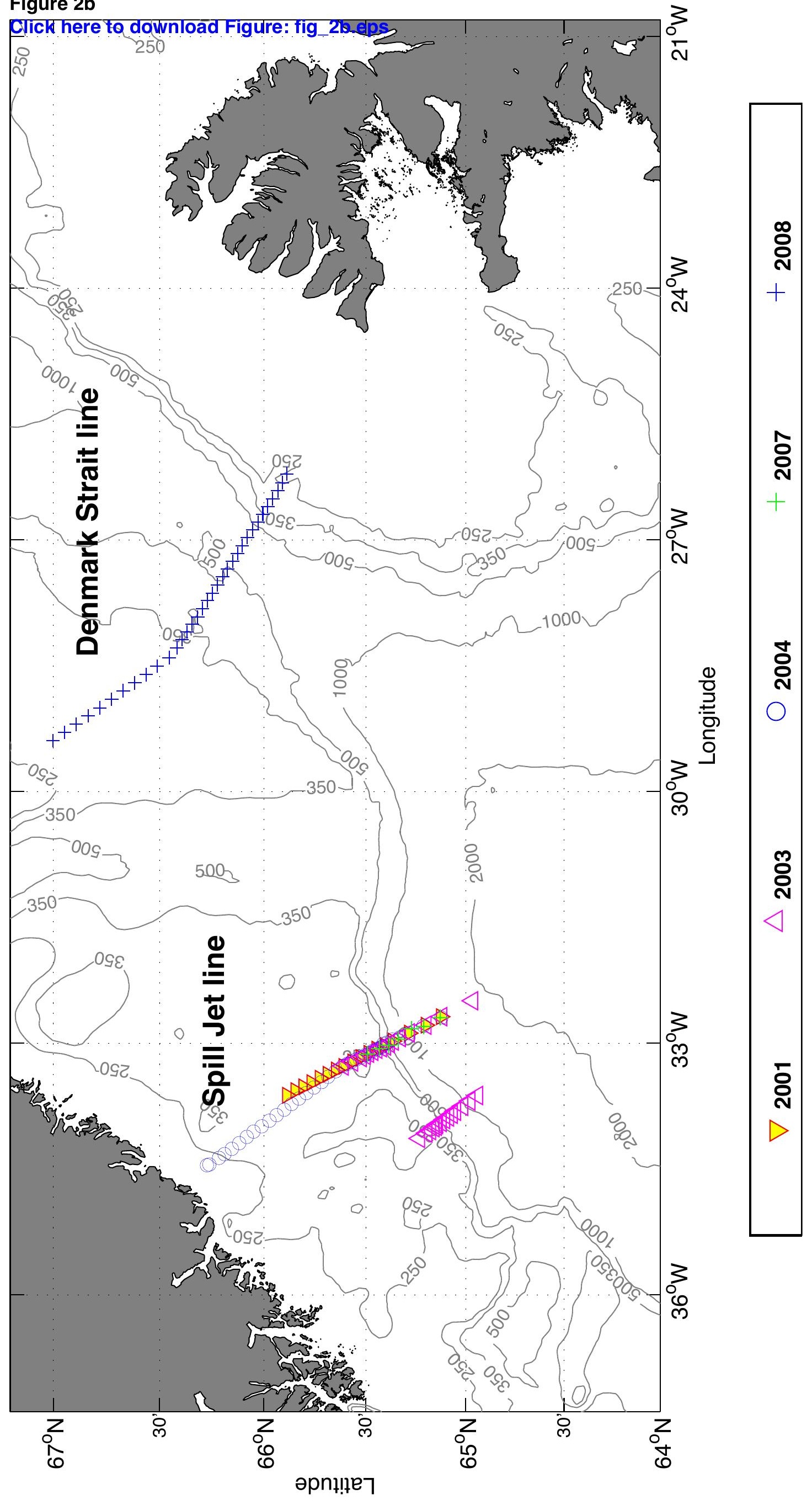




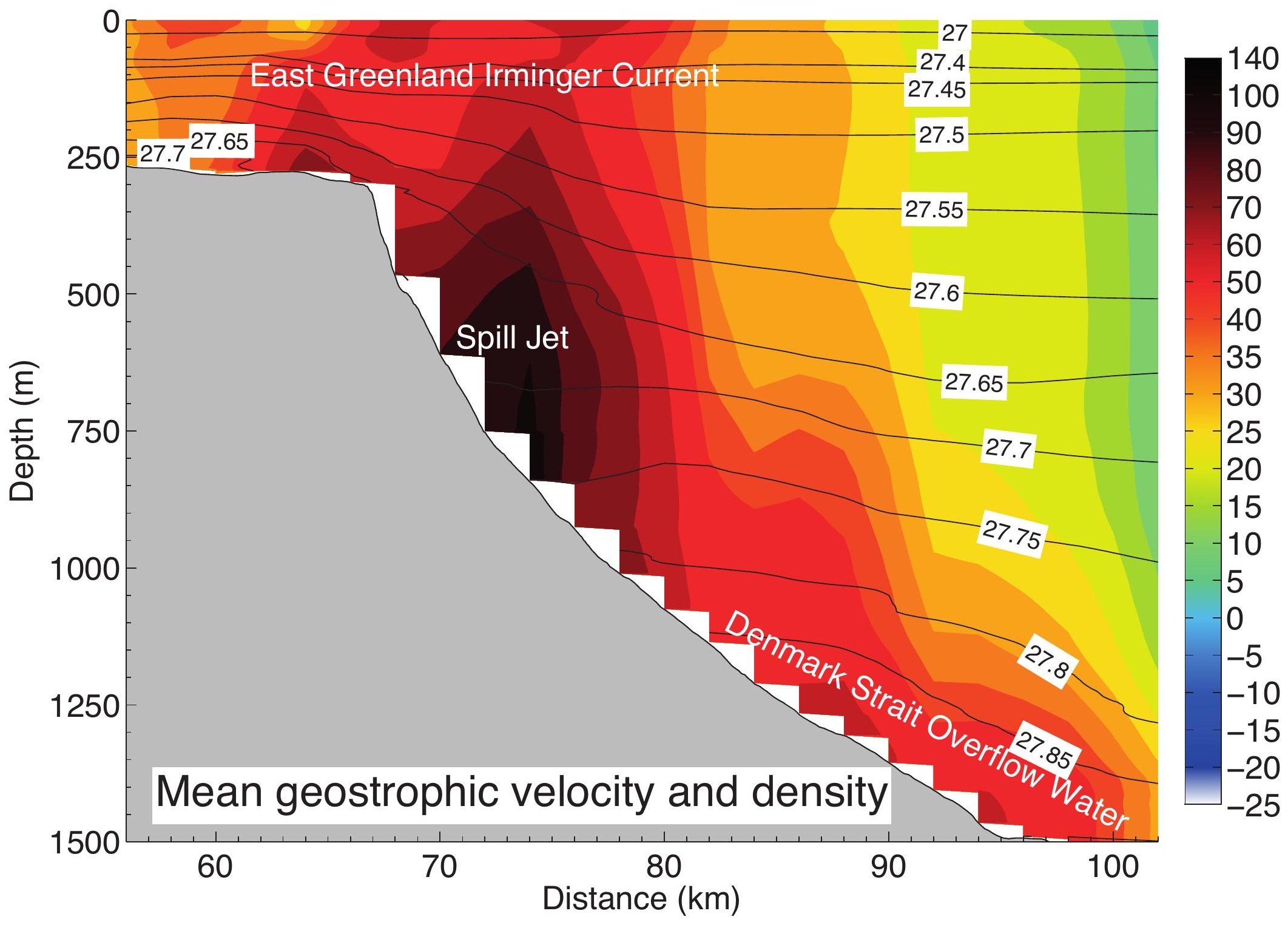



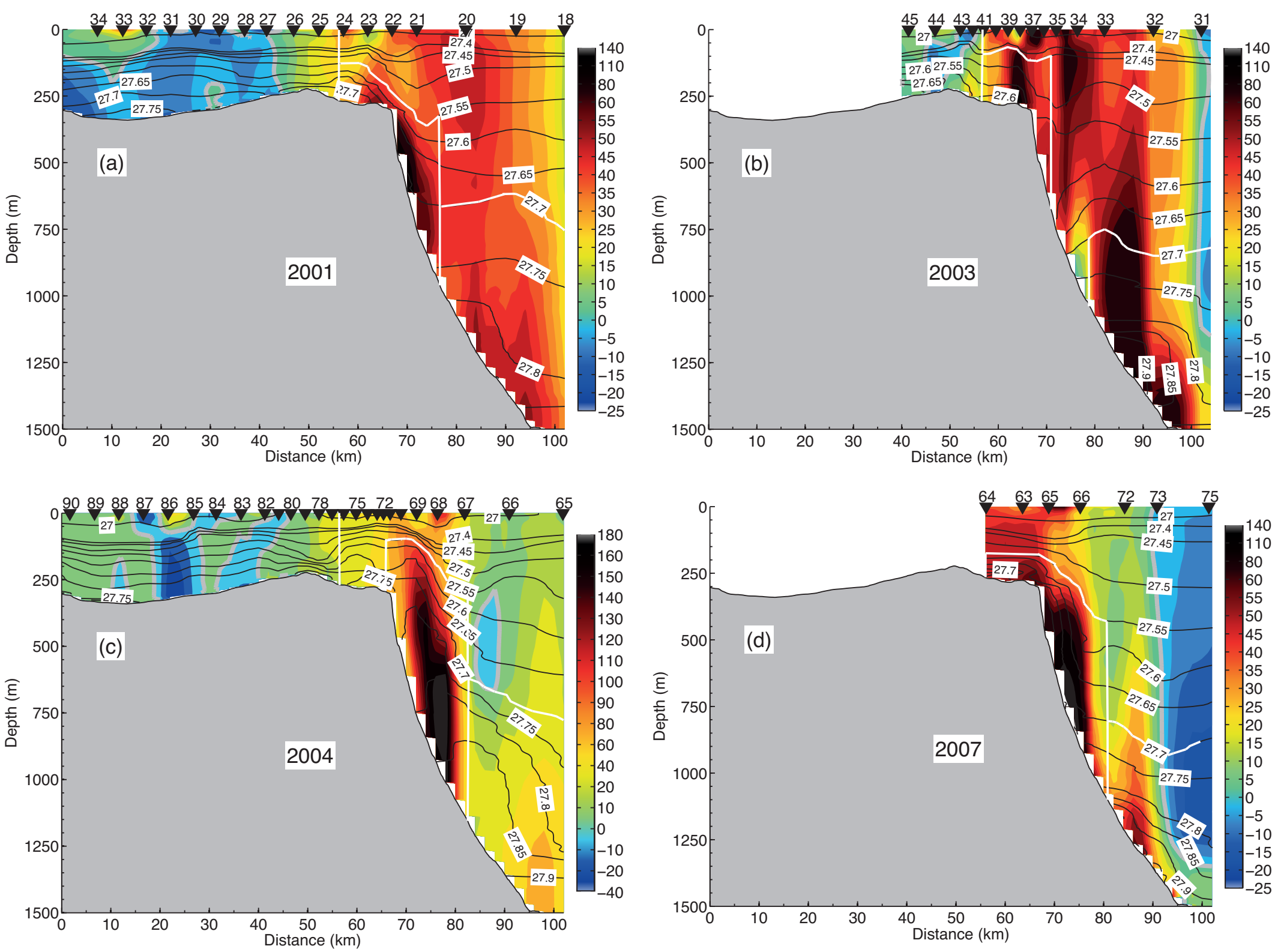

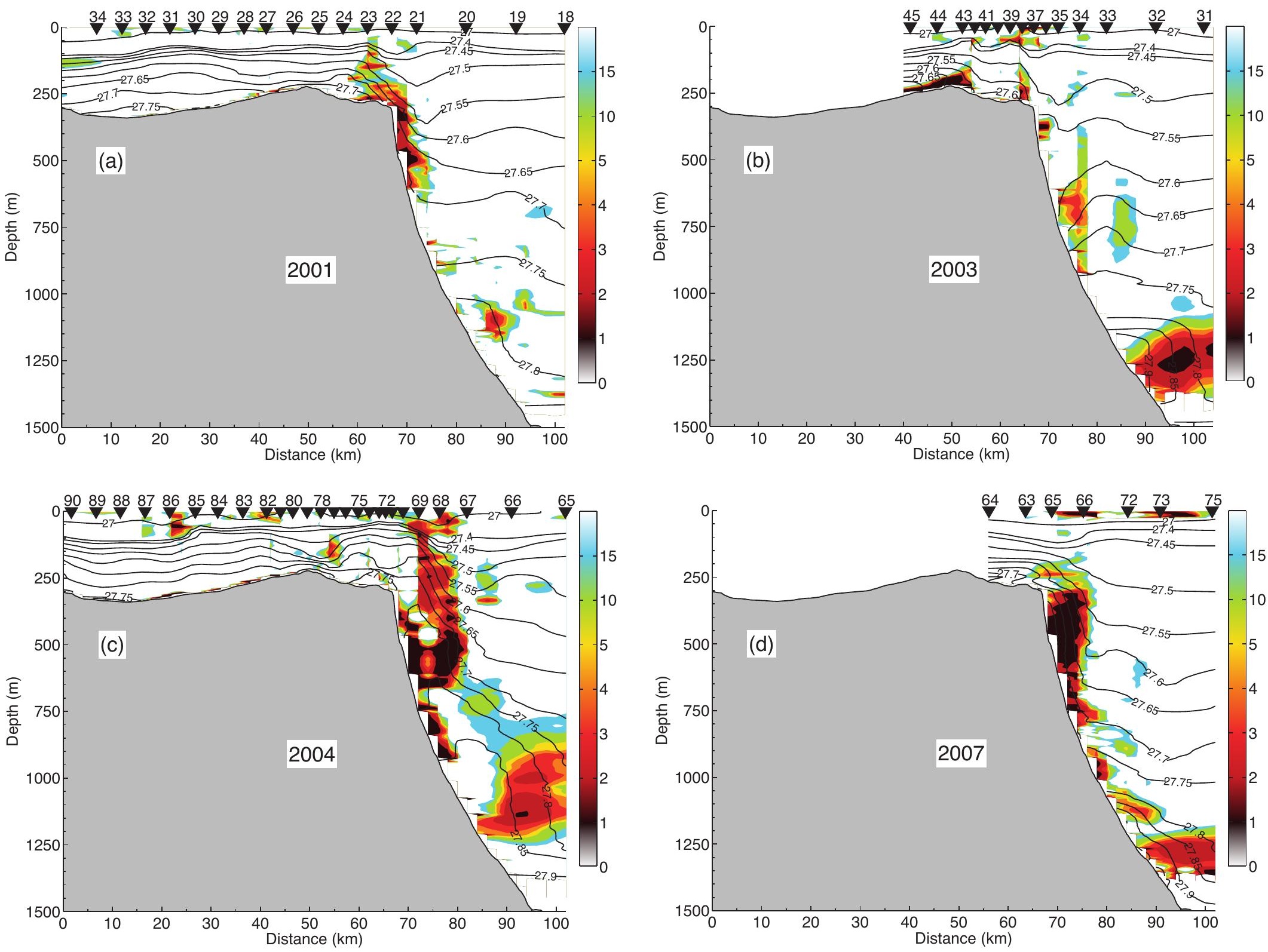

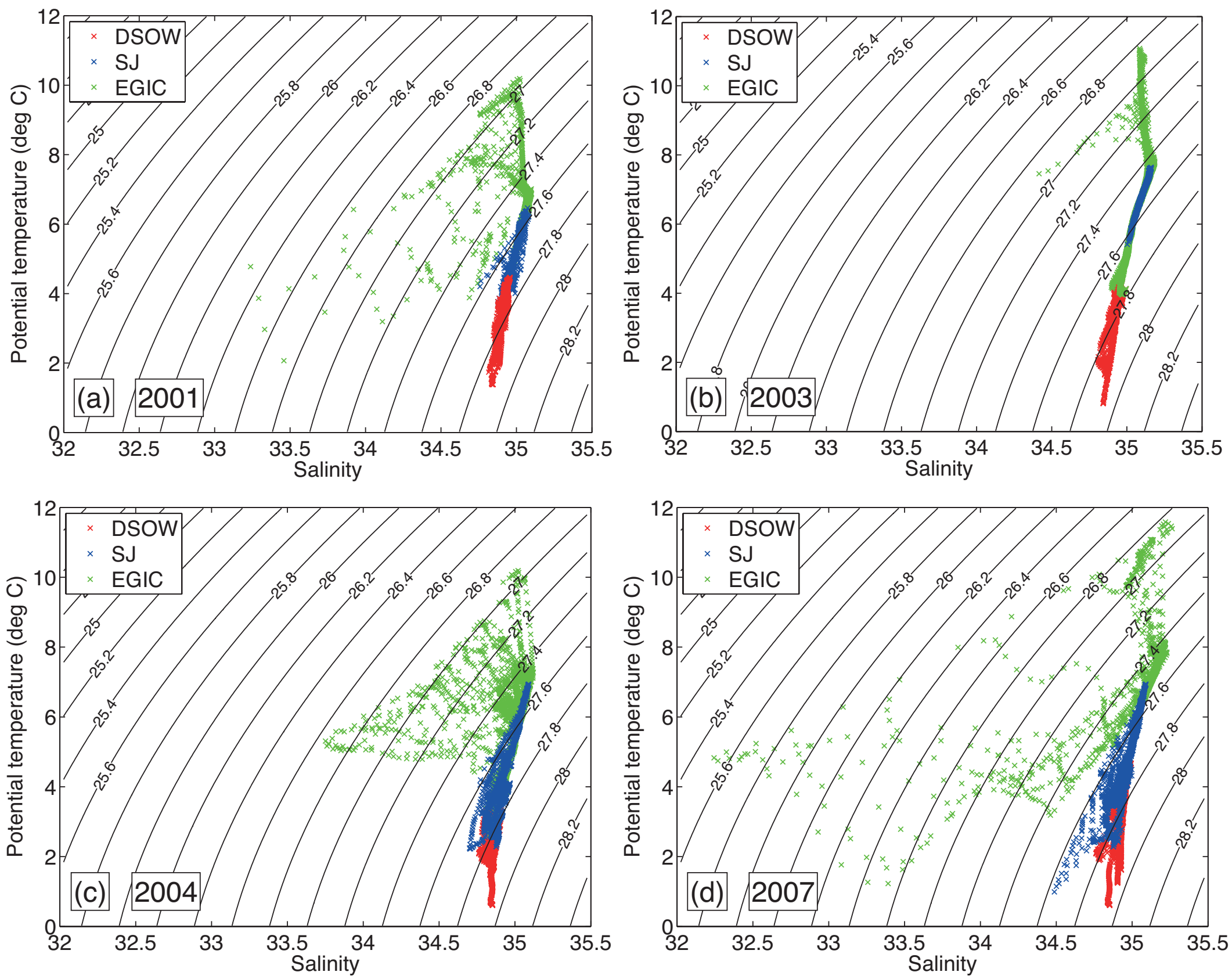


\section{Figure 9}

Click here to download Figure: fig_9.eps

\section{Denmark Strait Section}
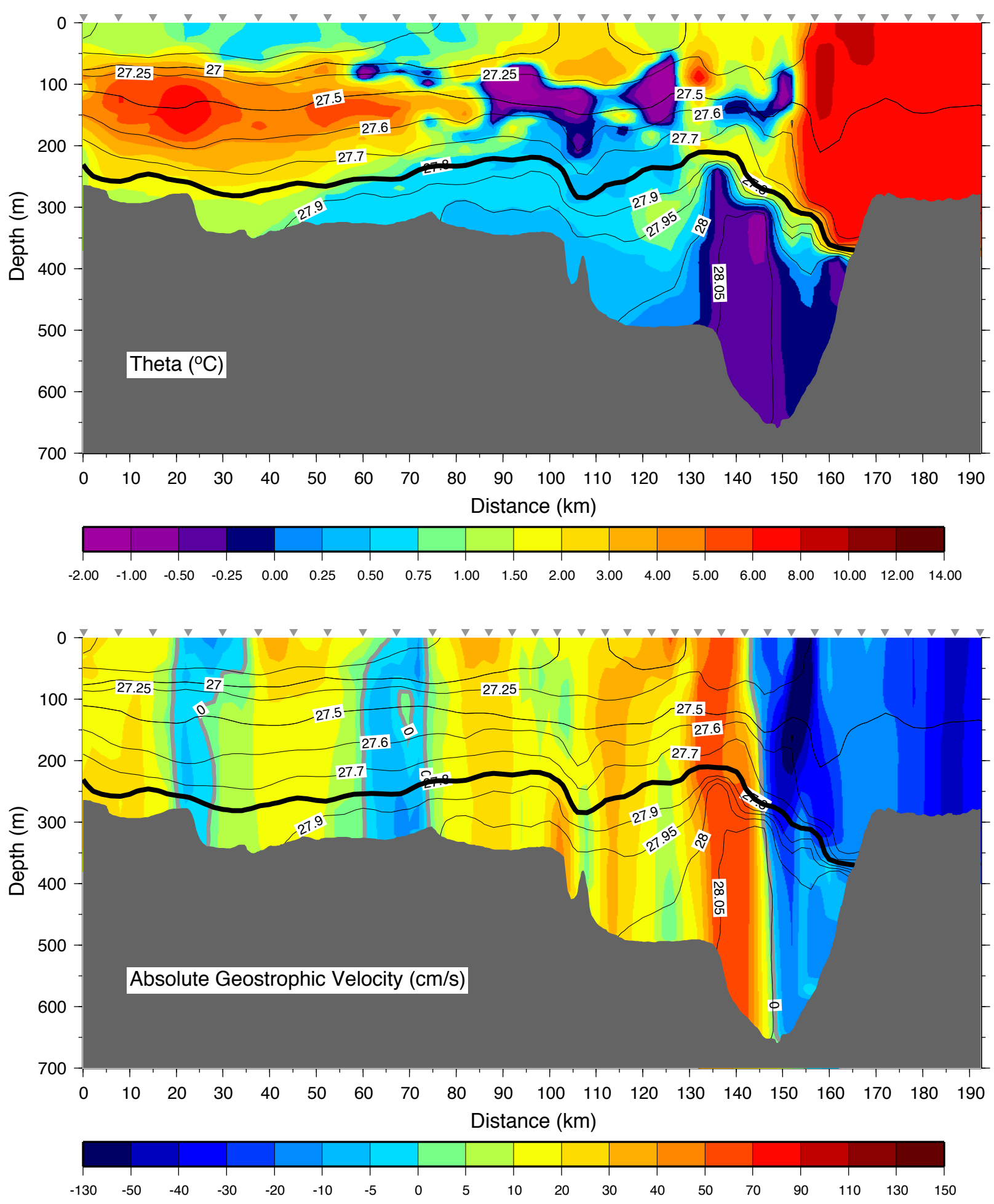

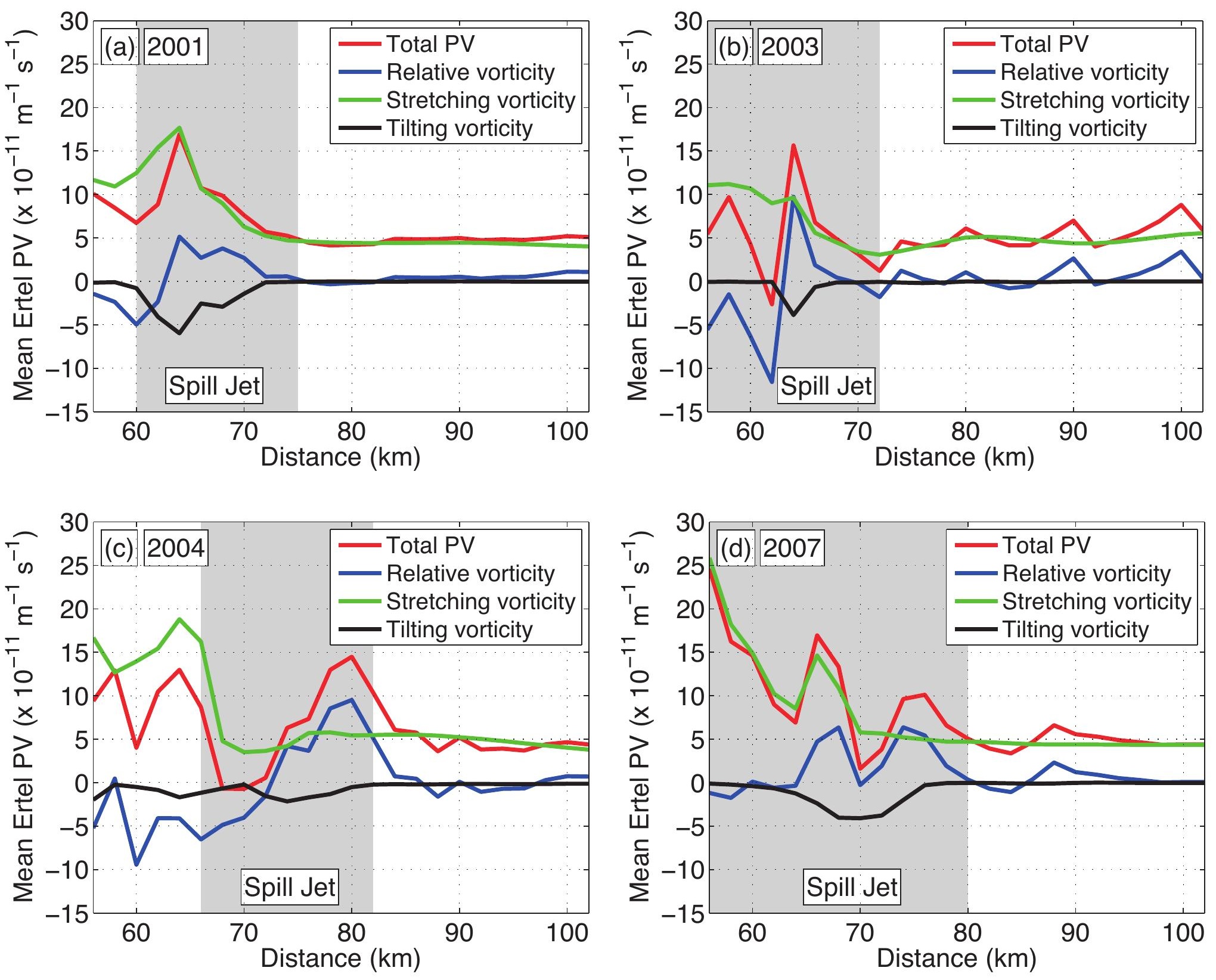
Figure 11

Click here to download Figure: fig_11.eps

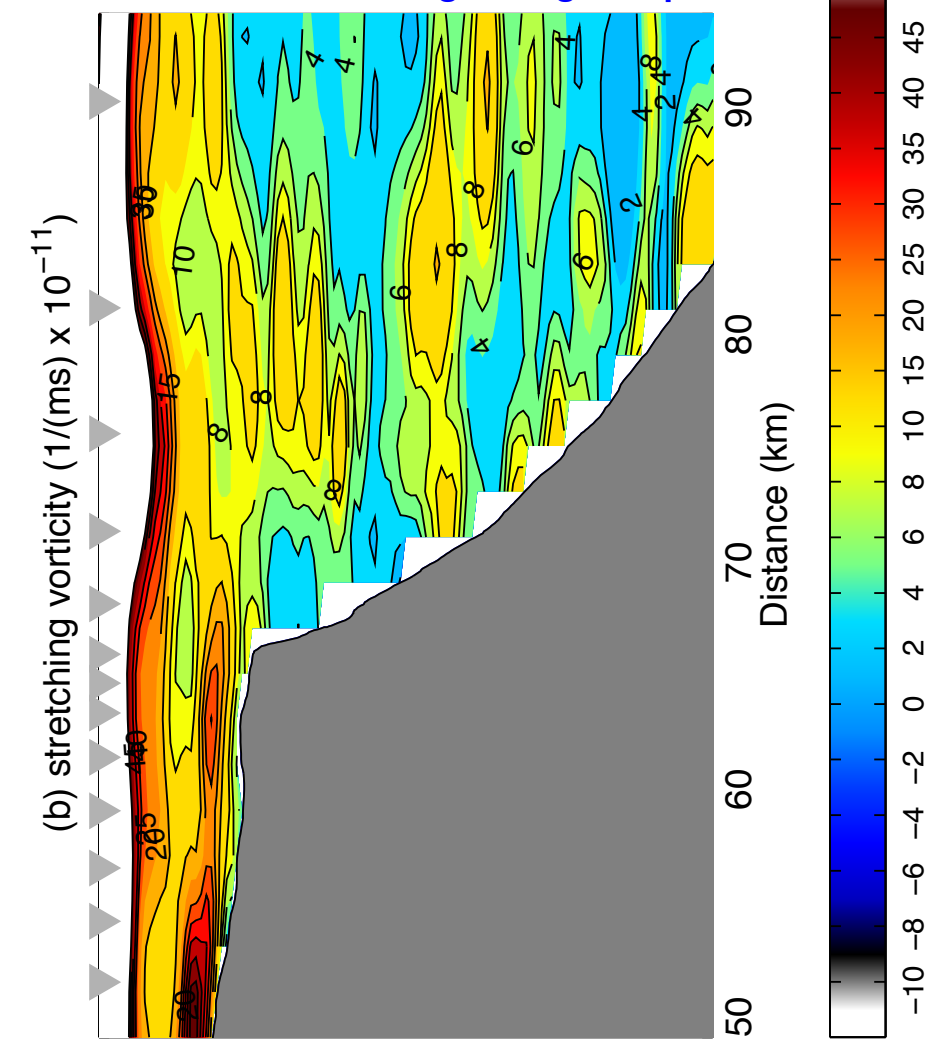
유 \&

(u) 4ıdə0

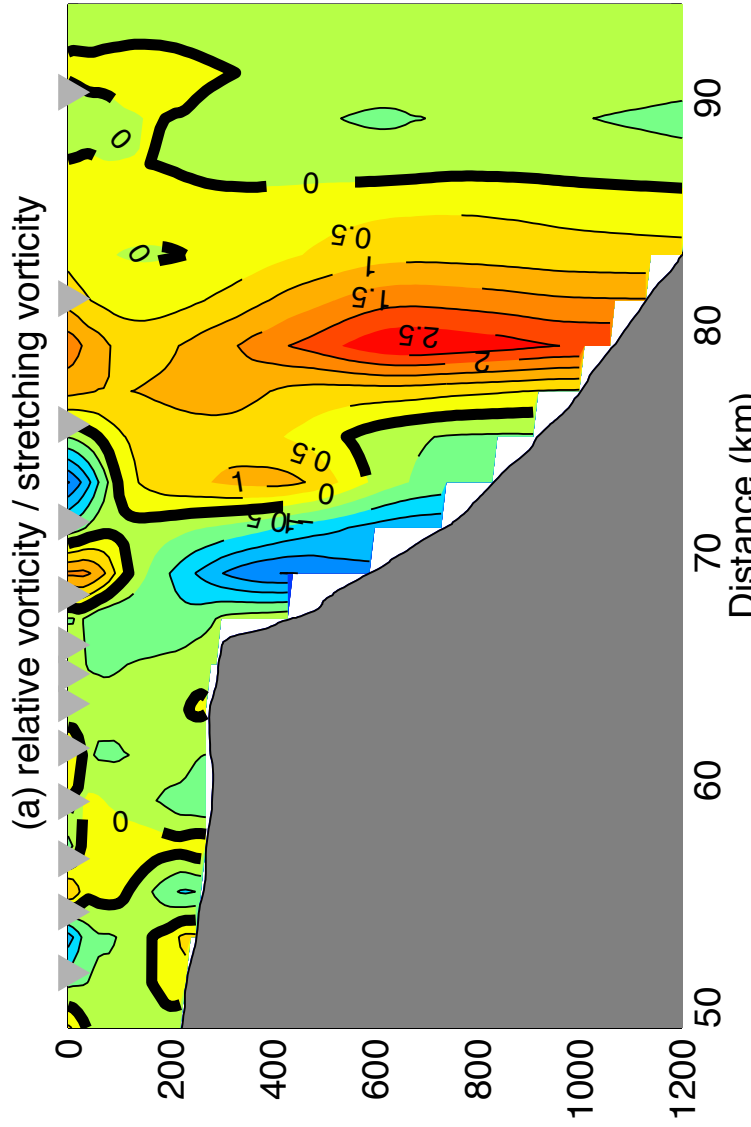

(u) पıdəح

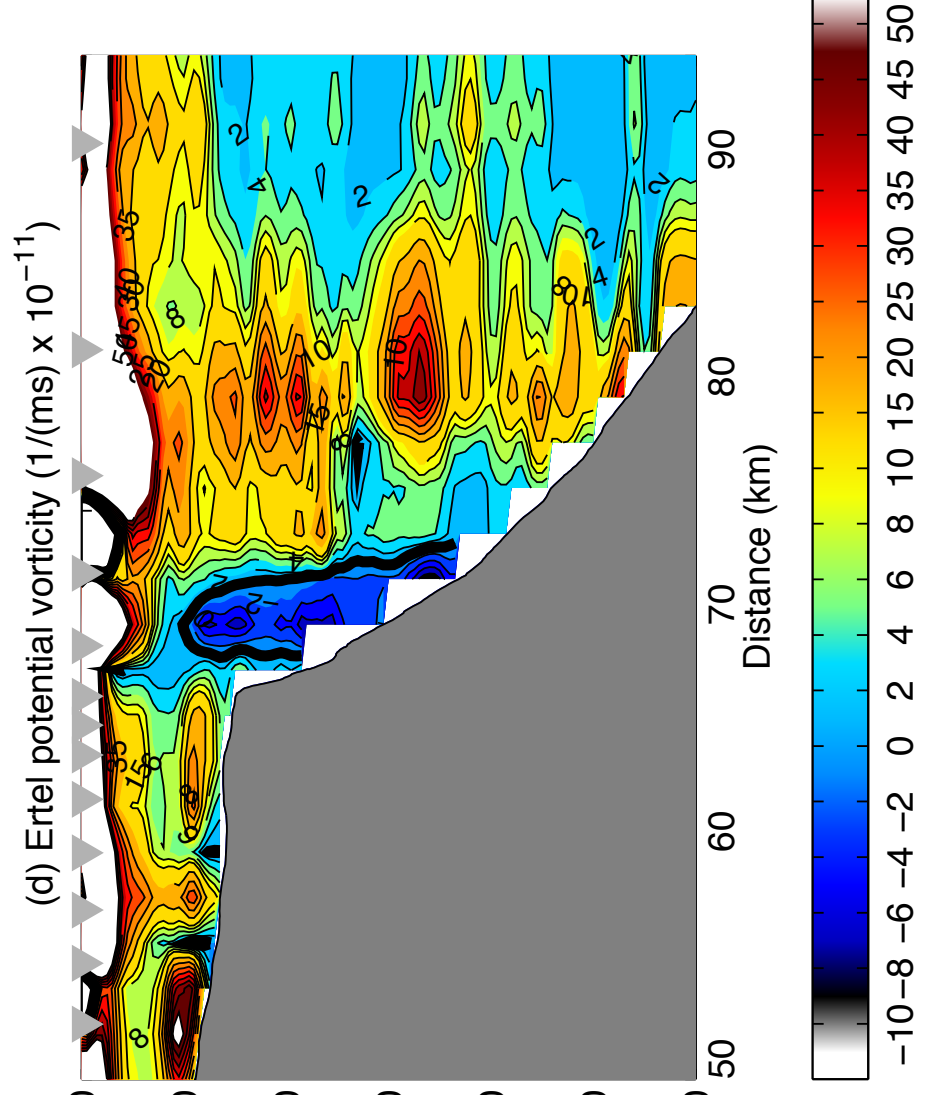

(w) पाdəव

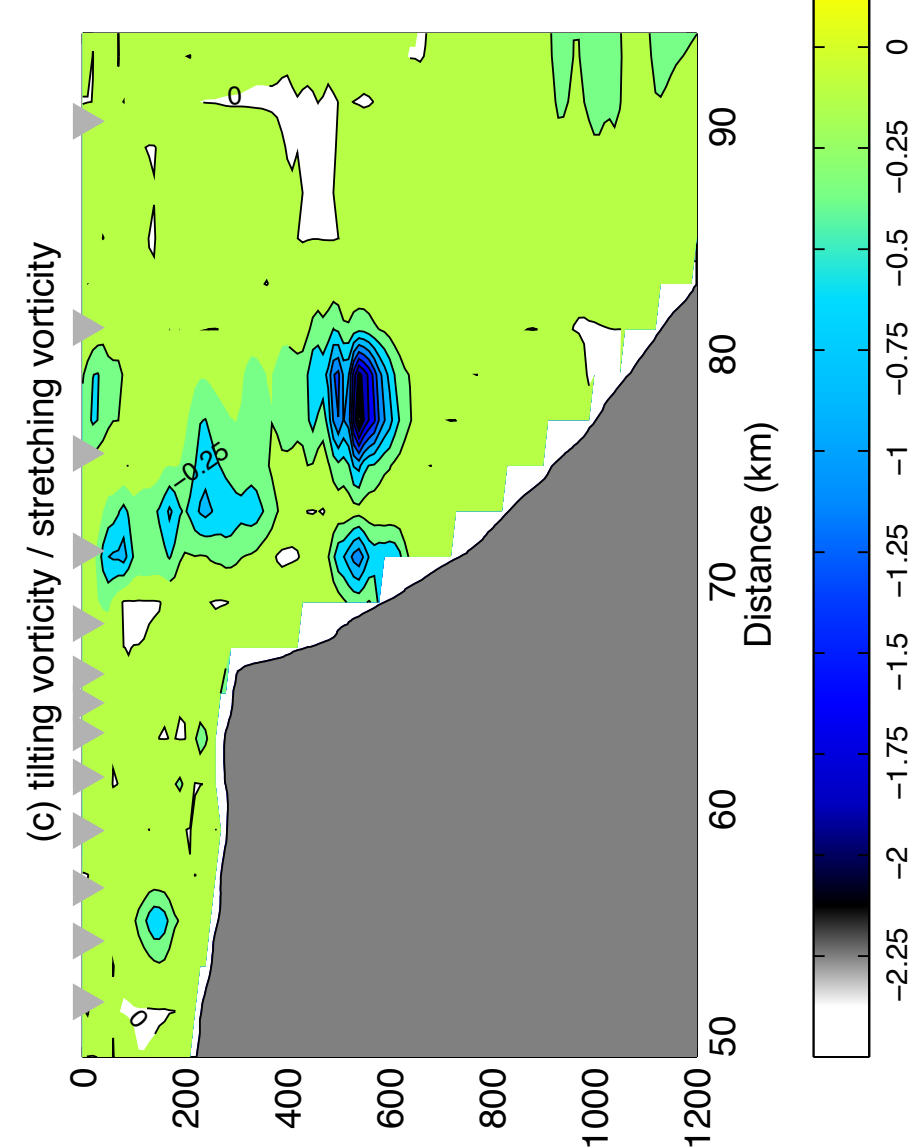

(u) чاdә0 


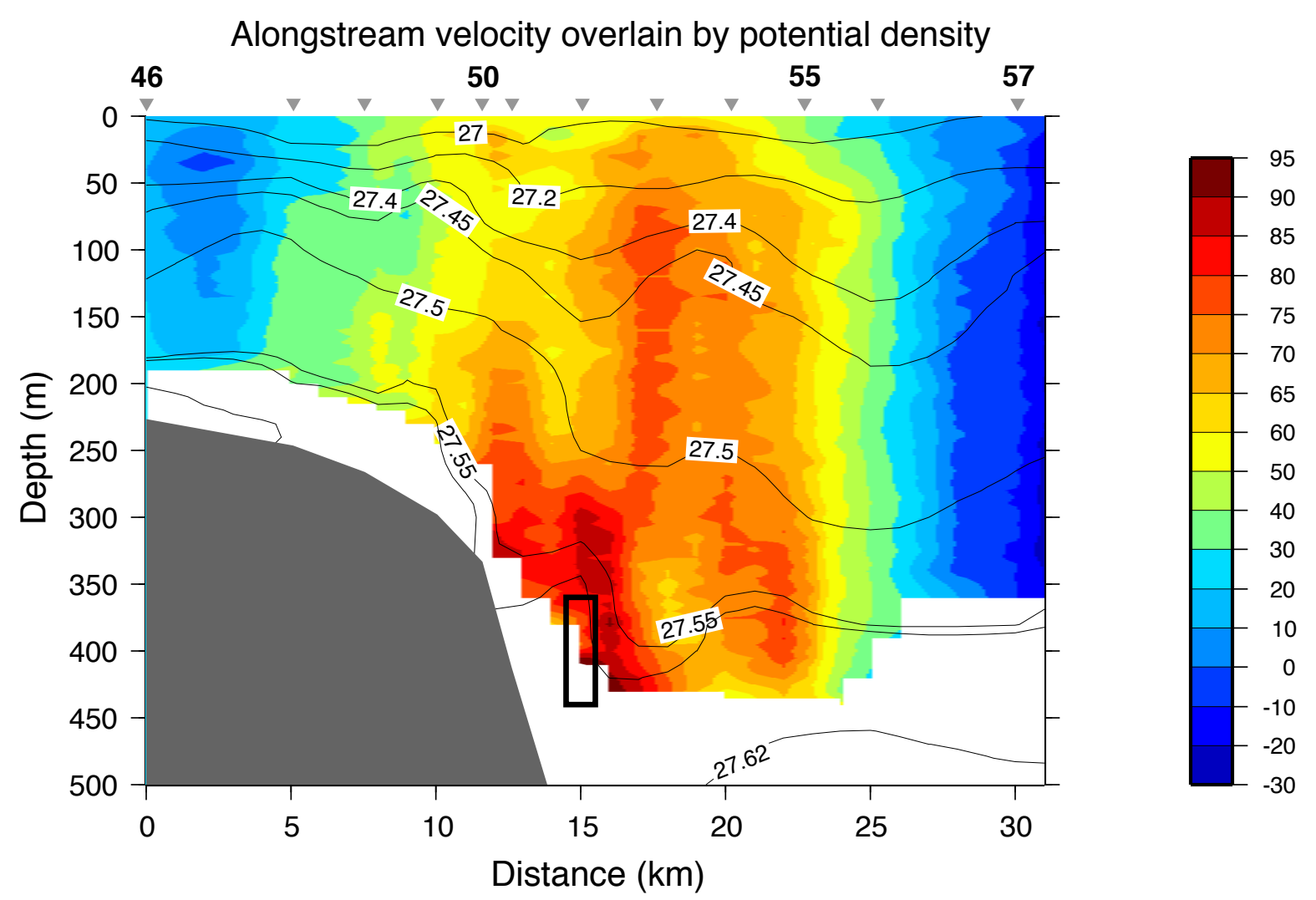




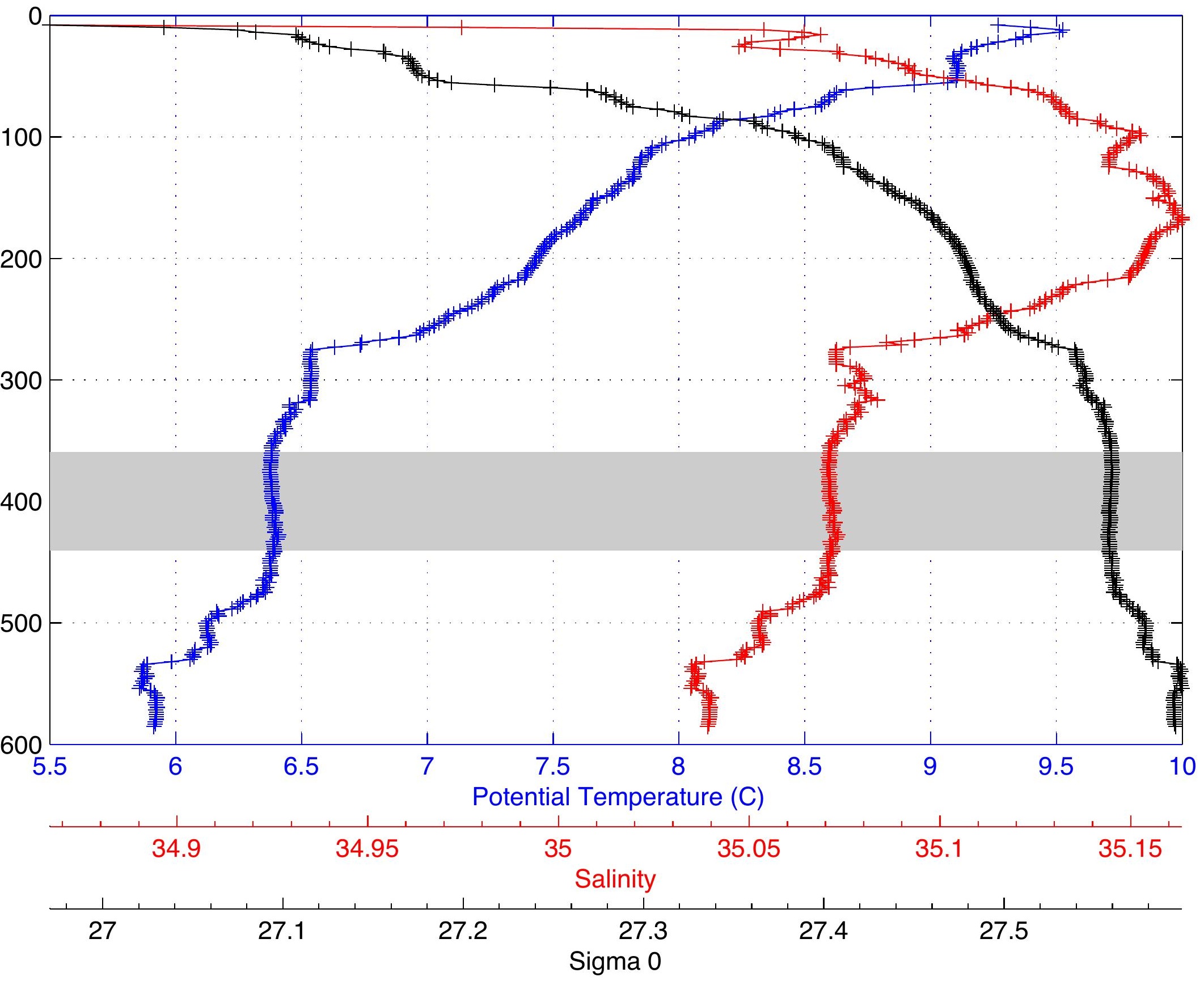



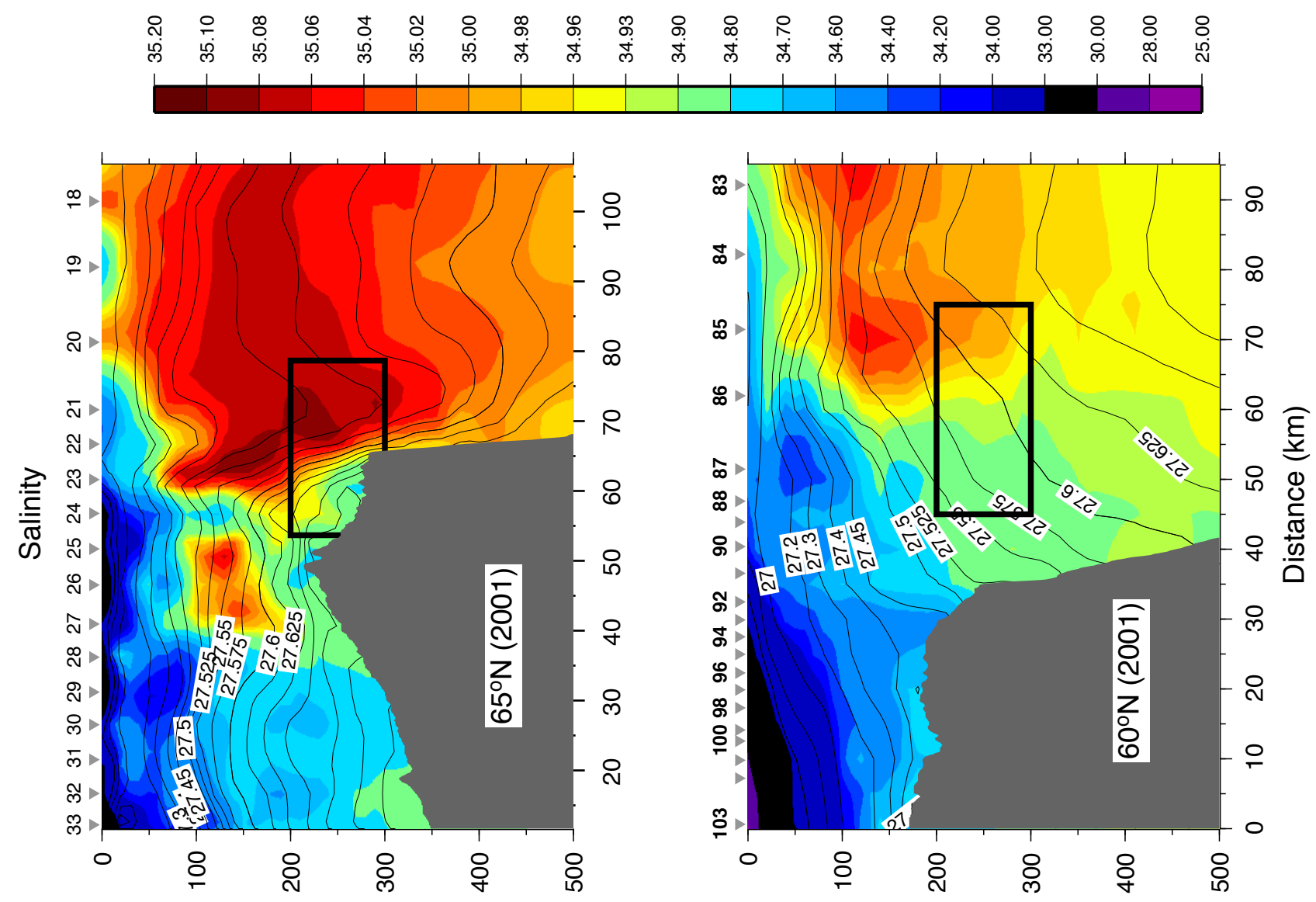

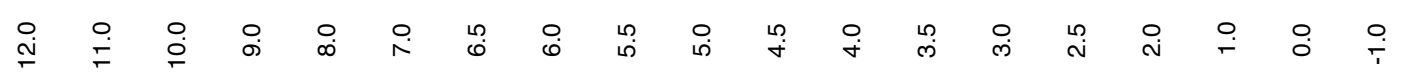

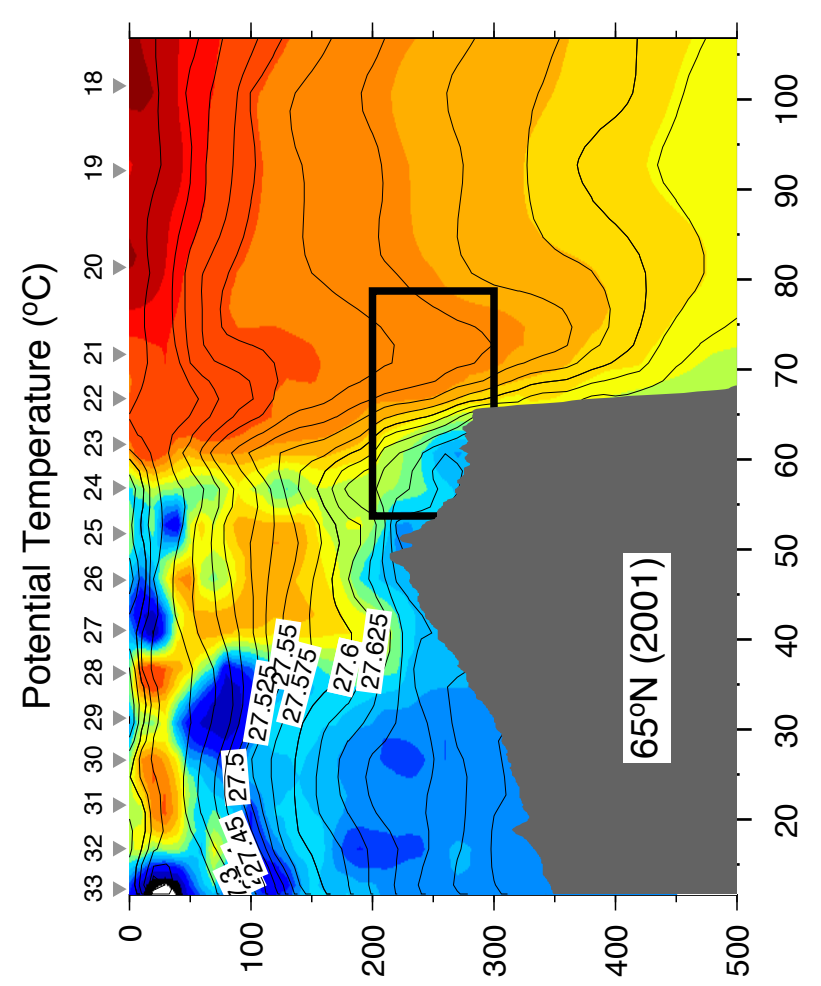

(w) पाdə0

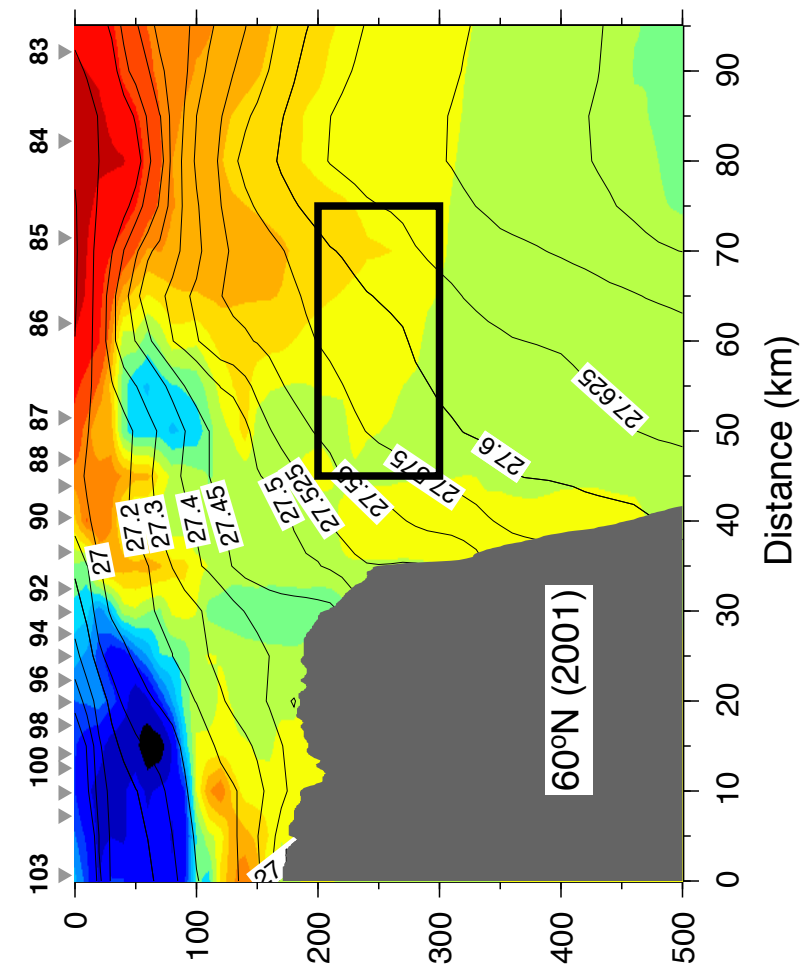

(u) पłdə0 

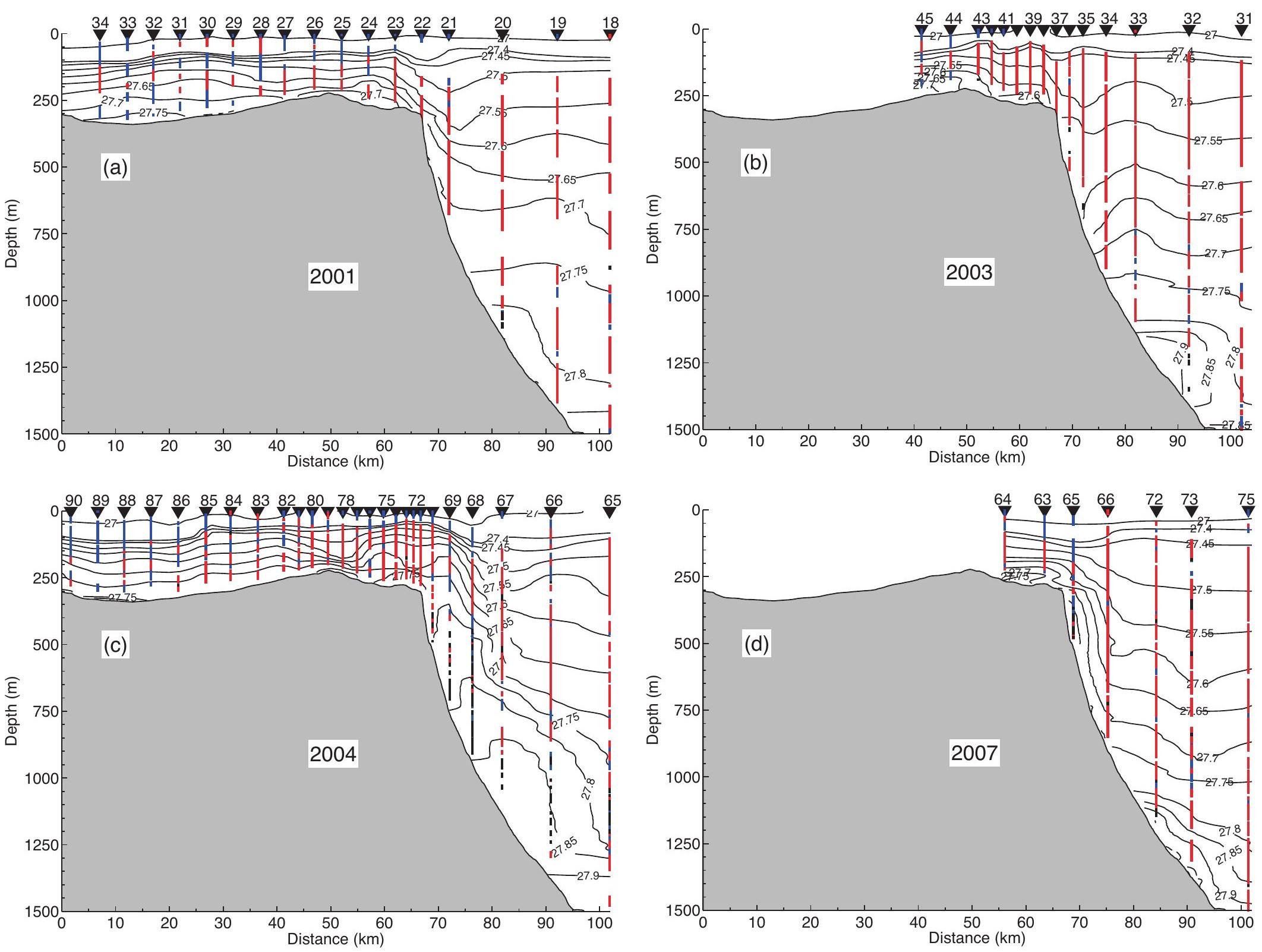

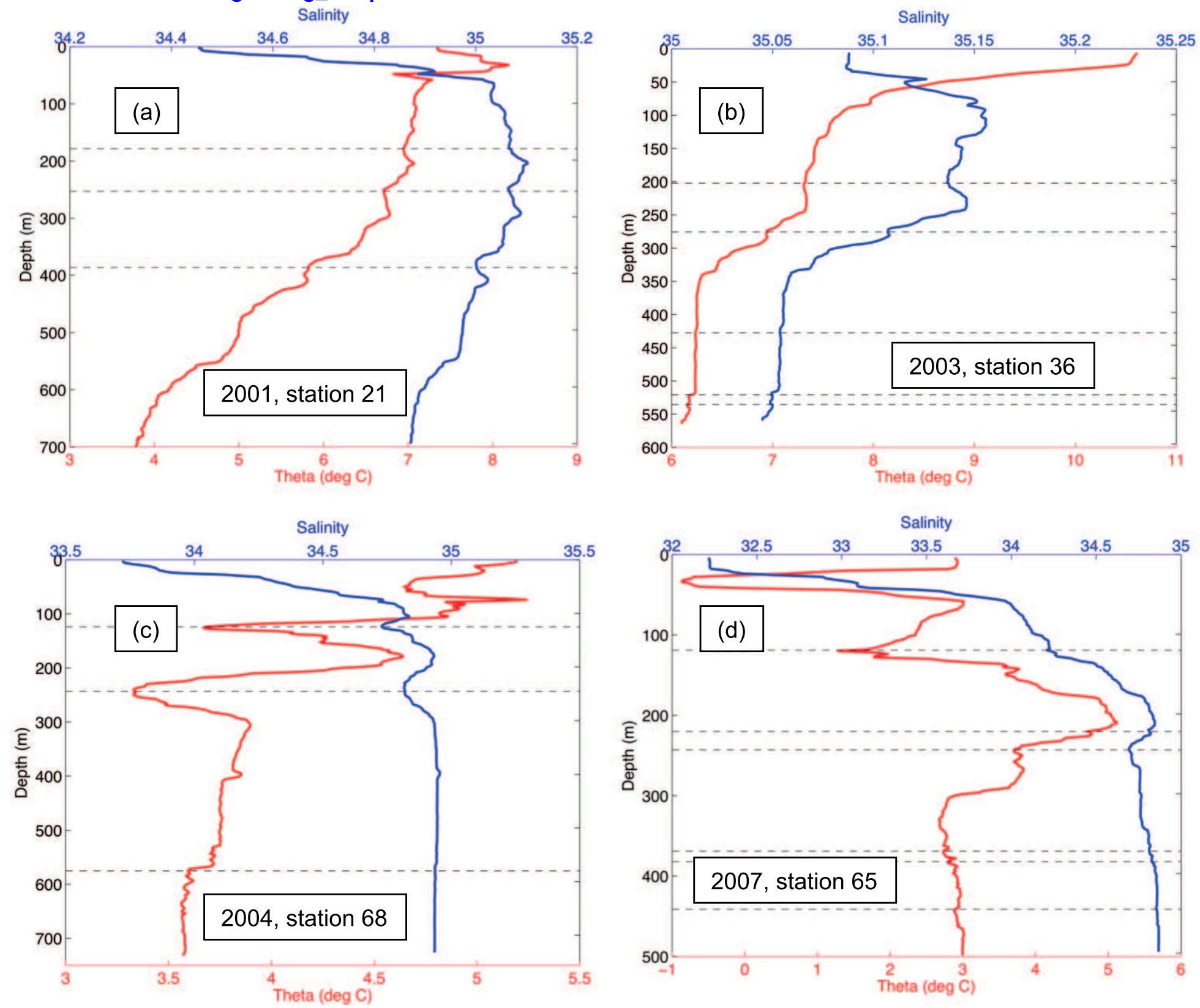
Click here to download Fig 185 fig $N$ 6.eps
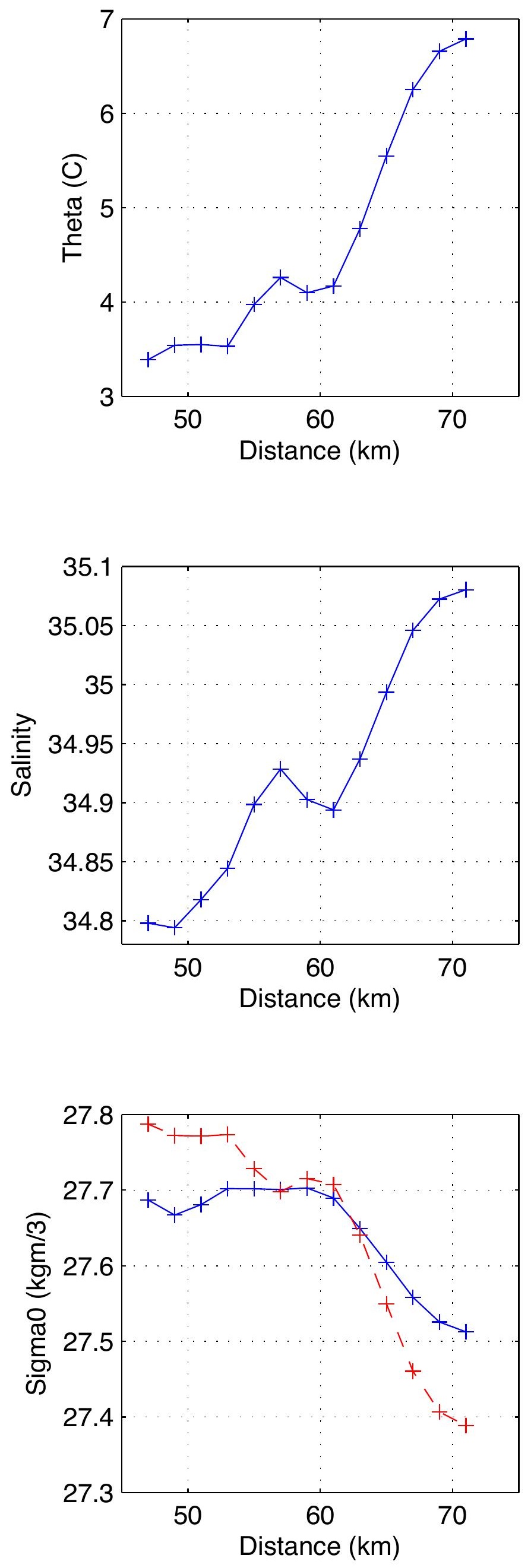

$60^{\circ} \mathrm{N}$
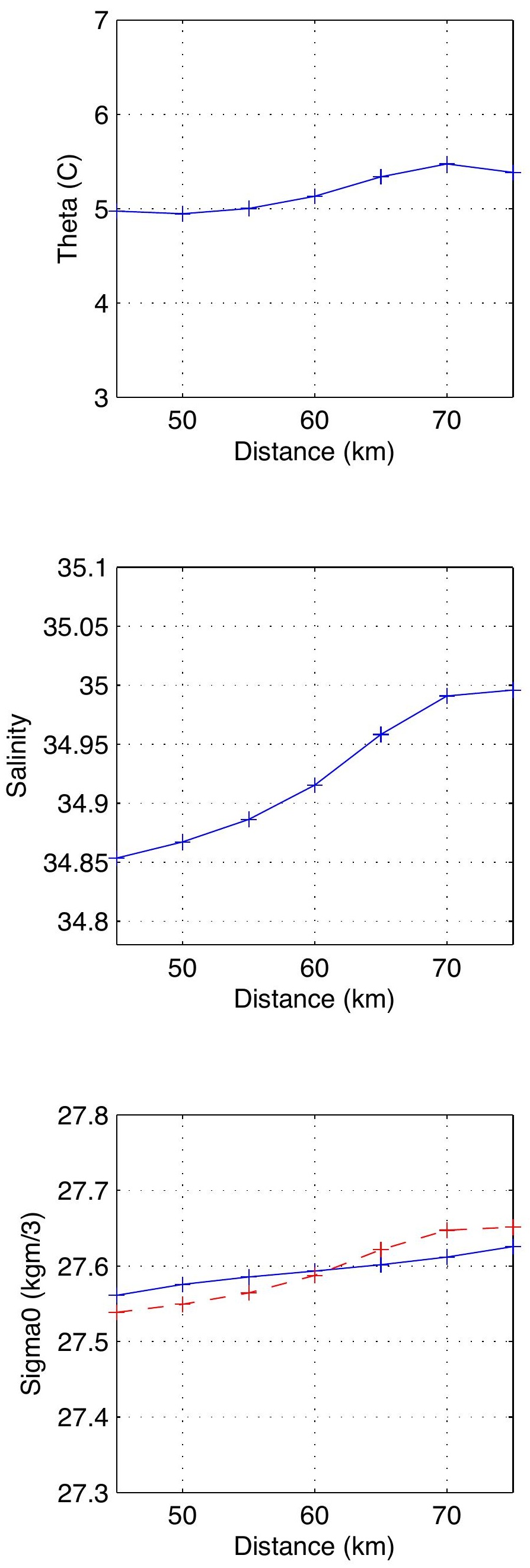